\title{
"Tilted" Justice: Site-Specific Art and Moral Rights After U.S. Adherence to the Berne Convention
}

\author{
Eric M. Brooks $\uparrow$
}

\begin{abstract}
Much of the congressional debate over the United States' adoption of the Berne Convention for the Protection of Literary and Artistic Works focused on the "moral rights" therein recognized. Yet soon after U.S. adherence, sculptor Richard Serra discovered that he remained unable to prevent the Federal Government from removing his site-specific sculpture "Tilted Arc" and was thus powerless to vindicate his moral rights. This Comment examines the development of moral rights and reviews the protection of those rights in the United States after accession to Berne. Through a consideration of site-specific art and the "Tilted Arc" case, the author argues that U.S. laws fail to protect the visual artist's moral rights even after Berne. The Comment concludes that federal legislation recognizing the moral rights of visual artists is imperative.
\end{abstract}

\section{INTRODUCTION}

In 1979, the General Services Administration (GSA) of the Federal Government commissioned American sculptor Richard Serra to create a work for the Federal Plaza at Foley Square in lower Manhattan. ${ }^{1}$ The sculpture, "Tilted Arc," was installed in 1981 and designed in keeping with Serra's formalist, minimalist aesthetic. ${ }^{2}$ Bisecting the small plaza, the monumental slab of corten steel curved slightly along its 120 -foot length and up its 12 -foot height. ${ }^{3}$ Serra intended to confront the viewer and the plaza itself, to " alter and dislocate the decorative effect of the plaza." "4

Serra believed that his agreement with the GSA assured the permanent installation of "Tilted Arc" because it was designed specifically for

$\dagger$ A.B., 1984 Yale University; J.D. candidate 1990, Boalt Hall School of Law, University of California, Berkeley.

1. See 1 J. Merryman \& A. Elsen, Law, Ethics and the Visual arts 358 (2d ed. 1987); Balfe \& Wyszomirski, Public Art and Public Policy, 15 J. ARTs Mgmt. \& L. 5, 6-9 (1986); Tomkins, Tilted Arc, New Yorker, May 20, 1985, at 95, 95-101. See generally S. Jordan, Public Art, Public Controversy: The Tilted Arc on Trial (1987).

2. Balfe \& Wyszomirski, supra note 1 , at 6 .

3. Id. at 6-7.

4. 1 J. MERRYMan \& A. Elsen, supra note 1, at 358 (quoting Serra). 
the location and hence was "site-specific"s - " "conceived and created in relation to the particular conditions of a specific site." "6 Such site-specific artwork uses its environmental surroundings to create its artistic effect. At a public hearing in March 1981, Serra described his work: "I don't make portable objects .... I am interested in a behavioral space in which the viewer interacts with the sculpture in its context."7 Serra maintained that "Tilted Arc" was artistically inseparable from Federal Plaza; its reinoval would destroy it. ${ }^{8}$

"Tilted Arc" was greeted with hostility by many of the federal workers in the area. ${ }^{9}$ Aesthetic and practical objections culminated in a petition drive led by a federal judge calling for the removal of the work. ${ }^{10}$ In the autumn of 1984 the GSA's regional administrator, William J. Dianond, decided to hold public hearings on the issue of relocating "Tilted Arc." ${ }^{11}$ Roughly 180 individuals testified during the March 1985 hearings, and more than 120 spoke for the retention of the piece. ${ }^{12} \mathrm{Nev}$ ertheless, Diainond and his panel determmed that the "Arc" should be reinoved and relocated, and the acting GSA administrator, Dwight Ink, endorsed this finding. ${ }^{13}$ Serra brought suit to prevent what he perceived as the destruction of the "Arc,"14 partially resting his claim on the theory that reinoval of the sculpture would violate his first amendnent rights. ${ }^{15}$ The district court rejected his arguinent, and the Second Circuit Court of Appeals affirmed. " "This Government . . . is eating its culture," Serra responded. ${ }^{17}$

"Tilted Arc" was scheduled to be dismantled on March 11, 1989, ${ }^{18}$ but the federal district court in Manhattan issued a teinporary

5. Id.

6. Serra v. United States Gen. Servs. Admin., 847 F.2d 1045, 1047 (2d Cir. 1988) (quoting Richard Serra).

7. 1 J. MERRYMAN \& A. ELSEN, supra note 1, at 358.

8. Serra, 847 F.2d at 1047.

9. N.Y. Times, Sept. 25, 1981, at C24, col. 1. The workers soon derided the sculpture as "The Berlin Wall of Foley Square." Solomon, Our Most Notorious Sculptor, N.Y. Times, Oct. 8, 1989, § 6 (Magazine), at 38, 74.

10. See 1 J. Merryman \& A. Elsen, supra note 1, at 360.

11. See 1 J. Merriman \& A. Elsen, supra note 1, at 360; Tomkins, supra note 1, at 95.

12. $1 \mathrm{~J}$. MERRYMAN \& A. ELSEN, supra note 1, at 360; Tomkins, supra note 1, at 95-96; see also N.Y. Times, Mar. 7, 1985, at B1, col. 1 (discussing the GSA hearings generally).

13. See Balfe \& Wyszomirski, supra note 1, at 8-9.

14. Serra v. United States Gen. Servs. Admin., 664 F. Supp. 798 (S.D.N.Y.), dismissed in part, 667 F. Supp. 1042 (S.D.N.Y. 1987), aff'd, 847 F.2d 1045 (2d Cir. 1988).

15. Id. at 801 (Count three of Serra's complaint stated that the relocation of the sculpture would violate his first amendment rights by depriving him of his right to artistic eommunication without governmental interference or suppression. Count four alleged constitutional torts based on the first and fourth amendments.).

16. Serra, 847 F.2d 1045 (2d Cir. 1988).

17. N.Y. Times, Mar. 11, 1989, $\S 1$, at 29, col. 2.

18. Id. 
restraining order barring removal until new legal arguments could be heard. ${ }^{19}$ Serra planned to argue that the moral rights clause of the Berne Convention for the Protection of Literary and Artistic Works, adhered to by the United States as of March 1, 1989, protected "Tilted Arc" from removal. $^{20}$ But on March 15, 1989, Serra abandoned his legal efforts after his attorneys advised him that neither the Berne Convention nor the federal act iniplementing adherence would bar the Federal Government from removing the "Arc."21 "People now recognize that lip service to Berne is hypocritical," Serra said. "It's a meamingless piece of paper."22 Workers completed removal of "Tilted Arc" from Federal Plaza on March 16, 1989. ${ }^{23}$

The loss of "Tilted Arc" forcefully illustrates the failure of U.S. laws to protect the visual artist's moral rights of paternity and integrity. Removal of any site-specific sculpture from its context, even if relocated mtact, by definition violates the integrity of the work, resultimg in its conceptual destruction. Unlike European civil law tradition, however, laws in the United States have not adequately recognized moral rights as legally protectable interests-even after the implementation of Berne. Consequently, current protections offer American artists an inadequate remedy to prevent the destruction of site-specific artworks.

This Comment will examine the protection of the visual artist's moral rights of paternity and integrity in the Umited States, with the sitespecific artist considered as an exemplar of the artist's situation, and "Tilted Arc" as the paradigniatic case of American failure. It will argne that current protections are madequate, and that adherence to Berne has added no additional protections. It will further argue that federal legislation creating waivable paternity and integrity rights is imperative to set the interests of the artist, the purchaser, and the public into proper balance, consistent with the American commercial tradition.

Part I will provide a background of the development of inoral rights in European jurisprudence and in the Berne Convention, illuminating the debate over the rights the United States agreed to protect when it adopted the Berne Convention. The rights of paternity and integrityparticularly questions regarding contextual integrity and destruction of artworks-will be exannined in light of the contractual formation issues of waiver and duration. The case for recognizing these rights explicitly will then be evaluated. Part II will critically assess the "minimalist" position toward American adherence to the Berne Convention, taken by

\footnotetext{
19. Id., Mar. 12, 1989, § 1, at 43, col. 1 .

20. Id.

21. Id., Mar. 16, 1989, at B2, col. 6 .

22. Id.

23. San Francisco Chron., Mar. 17, 1989, at E3, col. 1 .
} 
those who urge accession without any additional legislation to protect moral rights. After an explication of the terms of the Berne Implementation Act and its ramifications for site-specific artists, this Part will examine current protections of paternity and integrity interests asserted under the Copyright Act, the Lanham Act, state common law actions deemed analogous to moral rights actions, state moral rights statutes, and the first amendment. Part III argues for federal legislation amending the Copyright Act so as to protect moral rights. In so doing, the Comment notes the strengths and shortcomings of current Congressional proposals.

\section{I}

\section{MORAL RightS}

The recognition of moral rights is founded in the notion that works of art belong to their creators in a way that transcends the sale or transfer of the work to a new owner, because the artist has imbued the work with her personality. The artwork is an expression of the artist's soul, heart, and mind. As expressed by the artist Alfred Crimi, a work of fine art "is a one of a kind creation expressing the spirit and mood of the time of its conception and the psychological characteristics of the mind that conceives it. ... Once destroyed, its spirit cannot be recaptured, not even by the artist who conceived it."24 Recognition of moral rights helps preserve the authenticity of the artist's communication of her aesthetic vision. ${ }^{25}$ In recognizing that artists retain an interest in their artwork, moral rights carve out an exception to the personal property rights of the owner of the artwork by permitting the artist to control that property's integrity. By endowing artists with such power, a society not only safeguards artists from reputational harm but also preserves cultural property. ${ }^{26}$

Moral rights are "personal to [the] authors, and . . . [are] viable separate and apart from the proprietary aspect of copyright."27 When moral rights are recognized, they are generally considered to be rights of personality, rather than property rights protecting the artist's pecuniary

24. Visual Artists Rights Amendment of 1986: Hearing on S. 2796 Before the Subcomm. on Patents, Copyrights, and Trademarks of the Senate Comm. on the Judiciary, 99th Cong., 2d Sess. 12 (1986) (statement of Alfred Crimi, artist).

25. Bills Introduced and Senate Hearing Held on Visual Artist's Moral Rights, 38 PAT. TRADEMARK \& Copyright J. (BNA) No. 936, at 206 (June 22, 1989) (paraphrasing Professor Edward J. Damich).

26. Cuitural property has been defined as "objects that embody the culture-principally archeological, ethnographical, and historical objects, works of art, and architecture . . . " Merryman, The Public Interest in Cultural Property, 77 CaLIF. L. Rev. 339, 341 (1989).

27. 2 M. Nimmer \& D. Nimmer, Nimmer ON Copyright $\S 8.21$ [A], at 8-248 (1989). 
interest in the artwork. ${ }^{28}$ As such a personality right, the source of the artist's right is the artist herself. The law codifies and guarantees this right, which exists as soon as the artist has created the artwork. ${ }^{29}$ French law, for instance, views moral rights as deriving from the nature of artistic creation and from the "mystical presence of the author's personality in his work."30 Moral rights, while of judicial origin, have been codified in France and other civil law nations ${ }^{31}$ as well as in the Berne Convention. $^{32}$

The dominant components of moral rights are generally regarded to be the rights of paternity, integrity, and divulgation of the work. ${ }^{33}$ Other aspects of moral rights include the right to "repent or retake" a work, ${ }^{34}$ the right to modify a work, ${ }^{35}$ and the artist's right to prevent excessive criticism and other attacks on personality. ${ }^{36}$

Commentators addressing American recognition of moral rights focus chiefly on their two fundamental aspects, the rights of paternity and integrity. ${ }^{37}$ Article 6 bis of the 1971 revision of the Berne Convention for the Protection of Literary and Artistic Works recognizes only these two rights, ${ }^{38}$ although legislation of the member-nation governs

28. See Merryman, The Refrigerator of Bernard Buffet, 27 Hastings L.J. 1023, 1025 (1976); see also 2 M. NimMER \& D. NimMER, supra note 27, \$ 8.21[A], at 8-249 (noting some commentators' view that moral rights are inalienable because they are an element of the author's personality rather than a property right).

29. DaSilva, Droit Moral and Amoral Copyright: $A$ Comparison of Artists' Rights in France and the United States, 28 BULL. COPYRIGHT SOC'Y U.S.A. 1, 55 (1980).

30. Id. at 53 .

31. Merryman, supra note 28 , at 1026.

32. See infra note 38 and accompanying text.

33. See Kwall, Copyright and the Moral Right: Is An American Marriage Possible? 38 VAND. L. REV. 1, 5 (1985); Merryman, supra note 28, at 1027-28. See generally 1 S. LADAS, THE International Protection of ARTistic aNd Literary Property $\$ \$ 272-287$ (1938); Amarnick, American Recognition of the Moral Right: Issues and Options, 29 COPYRIGHT L. SYMP. (ASCAP) 31, 31 (1983); Diamond, Legal Protection for 'Moral Rights' of Artists and Other Creators, 68 TRADEMARK REP. 244, 245 (1978); Roeder, The Doctrine of Moral Right: A Study in the Law of Artists, Authors and Creators, 53 HARv. L. REv. 554, 559-72 (1940); Rosen, Artists' Moral Rights: $A$ European Evolution, an American Revolution, 2 CARDozo ARTS \& ENT. L.J. 155, 155 (1983); Sarraute, Current Theory on the Moral Right of Authors and Artists Under French Law, 16 AM. J. CoMp. L. 465, 467-83 (1968).

34. Merryman, supra note 28 , at 1028.

35. Id.

36. Diamond, supra note 33, at 255.

37. See, e.g., Nimmer, Implications of the Prospective Revisions of the Berne Convention and the United States Copyright Law, 19 STAN. L. REv. 499, 520-23 (1967); see also Amarnick, supra note 33, at 32; Merryman, supra note 28, at 1042-49.

38. Berne Convention for the Protection of Literary and Artistic Property, Sept. 9, 1886, 123 L.N.T.S. 233, reprinted in 4 M. NIMMER \& D. NIMMER, NIMMER ON COPYRIGHT, App. § 27-5 (1989) [hereinafter Berne Convention]. The current article 6bis provides:

(1) Independently of the author's economic rights, and even after the transfer of said rights, the author shall have the right to claim authorship of the work and to object to any 
substantive application. ${ }^{39}$

\section{A. Protection of Paternity and Integrity}

The artist's right to paternity is comprised of three elements: her right to prohibit the affixation of her name to another's work; the right to demand affixation of her name to her work; and the right to prohibit the affixation of another's name to her work. ${ }^{40}$ Empowering the artist to claim authorship of her work recognizes that she has imbued it with her own personality and therefore should be able to claim credit for that creative and personal act and direct how the work is to be attributed. ${ }^{41}$ Thus, the right also guarantees that the artist may preserve her privacy by employing a pseudonym or by displaying her work anonymously. ${ }^{42}$ The paternity right would protect a site-specific artist like Serra from the affixation of another artist's name to "Tilted Arc" and would also assure his ability to affix his chosen name to the work.

The second fundamental moral right is the artist's right to integrity of the artwork. As the paternity right does, the right of integrity protects the personality of the artist. Since a work of art expresses or embodies the artist's personality, any distortion, mutilation, or misrepresentation of the work injures that expression, and impairs her interest in identity, personality, and honor. ${ }^{43}$ In addition, any act modifying the work injures the artist's personality and dignity. ${ }^{44}$

In the European context, it las been unclear whether the integrity right could, in principle, previent the complete destruction of a work of art. Thus, even if the United States did recognize the moral right to

distortion, mutilation or other modification of, or other derogatory action in relation to, the said work, which would be prejudicial to his honor or reputation.

(2) The rights granted to the author in accordance with the preceding paragraph shall, after his dcath, be maintained, at least to the expiry of the economic rights, and shall be exercisable by the persons or institutions authorized by the legislation of the country where protection is claimed. However, those countries whose legislation, at the moment of their ratification of or accession to this Act, does not provide for the protection after the death of the author of all the rights set out in the preceding paragraph may provide that some of these rights may, after his dcath, cease to be maintained.

(3) The means of redress for safeguarding the rights granted by this Article shall be governed by the legislation of the country where protection is claimed.

Berne Convention, supra.

39. See id. Art. 6bis (3); Kwall, supra note 33, at 11.

40. See $1 \mathrm{~S}$. LADAS, supra note $33, \S 280$, at 585 .

41. See DaSilva, supra note 29 , at 26 (discussing the French recognition of the paternity right).

42. See Diamond, supra note 33, at 254-55 (discussing the application of the paternity right).

43. Merryman, supra note 28, at 1027. Merryman explores at length the case of the artist Bernard Buffet, who painted six panels of a refrigerator, intending the work to be one painting. Invoking the right of integrity, Buffet was able to prevent the sale of one panel which had been removed. Id. (citing Judgment of May 30, 1962, Cour d'appel, Paris, 1962 Recueil Dalloz [D. Jur.] 570).

44. See Damich, The New York Artists' Authorship Rights Act: A Comparative Critique, 84 Colum. L. REV. 1733, 1742 (1984). 
integrity, it would remain uncertain whether the GSA could nevertheless completely destroy "Tilted Arc."45

One rationale for treating destruction as an exception to the integrity right is that once destroyed, a work cannot reflect poorly upon an artist's reputation or honor. ${ }^{46}$ If the destruction subjects the artist to humiliation or disgrace, however, as the very public removal of "Tilted Arc" arguably did to Serra, sucli an exception might not be observed. ${ }^{47}$ In any case, total destruction should violate the imtegrity riglit because integrity is a personality right. Even if the work is destroyed privately, the artist herself suffers an impairment of her expression of personality. Moreover, the destruction prevents the public from enjoying the artist's work ${ }^{48}$ and causes omissions in the artist's total body of work, thereby impairing the public's ability to appreciate the artist's true progression of style. Fimally, destruction of a piece may interfere with the artist's paternity rights, by depriving her of lier right to direct liow the piece is to be attributed. ${ }^{49}$

One question of particular relevance to tlie site-specific artist is whether placing a work in an offensive context violates the right of integrity. ${ }^{50}$. The Soviet composer Shostakovich and his fellow plaintiffs raised the issue of offensive context when they objected to the imcorporation of their music in an American motion picture that had an "anti-communist" theme. The plaintiffs sued in tlie United States and France, arguing that the placement of their compositions in such an offensive context

45. For example, in France, courts have reached opposite conclusions on this issue. A 1934 case involved frescoes painted by one Lacasse without the knowledge of the chapel's owner. The owner ordered the frescoes effaced, and the court found in his favor. Judgment of Apr. 27, 1934, C.A. Paris, 1934 D. Jur. 385. Two years later, after creating a statue for a town's fountain, the sculptor Sudre found his statue removed, destroyed, and used to fill potholes. The court found that the artist's moral right of integrity had been violated. Judgment of Apr. 3, 1936, Conseil d'Etat (Administrative Court), Fr., 1936 Recueil Pèriodique et critique [D.P.] III 57. More recent European cases, including a decision by the Supreme Court of France, have also recognized that the personal rights of authors include the right to prevent destruction. Damich, supra note 44, at 1742 \& n.71 (citing Judgment of Mar. 16, 1983, Cour de cassation (Supreme Court), Première section civile [Cass. civ. 1re] Fr., 1983 Recueil Dalloz-Sirey [D.S. Jur.] 432).

46. See Roeder, supra note 33 , at 569 .

47. Diamond, supra note 33, at 258; see also Amarnick, supra note 33, at 56-58 (examining justifications for including in the moral right the right to prevent destruction).

48. See Ainarnick, supra note 33 , at 57.

49. Merryman, supra note 28 , at 1035 .

50. A related problem arises when the work remains in its original context but an offensive element is added. Maya Ling Lin, the designer of the Vietnam Veterans Memorial, inight have plausibly argued that the addition of Frederick Hart's statuary and flagpole to the memorial site violated her right to the integrity of the work. Maya Ling Lin intended the memorial to include not only the black wall, but the grassy approach to it as well. The statuary arguably interferes with this intention by drawing approaching observers away from the wall and thereby altering the memorial itself. See generally 1 J. MERRYMAN \& A. ELSEN, supra note 1, at 348-51 (discussing the vision behind Maya Ling Lin's memorial and the controversy over the addition of Frederick Hart's statuary to the site). 
constituted an infringement of their interest in the integrity of their art. The case illustrates the difference between French and American protection of artists' rights: The American court explicitly denied the moral rights claim, ${ }^{51}$ while on identical facts, a French court hearing the case found a violation..$^{52}$ More importantly, the French decision shows that a court in a nation adhering to the Berne Convention should find that an objectionable context violates a work's integrity, ${ }^{53}$ for it results in a misrepresentation of the artist's personality just as a mutilation would.

\section{B. Alienation and Duration}

While moral rights are considered inalienable in France and numerous other countries, ${ }^{54}$ inalienability is not essential to the recognition of moral rights, ${ }^{55}$ for both the Berne Convention and Gerinan law provide that the rights are alienable in express agreements. ${ }^{56}$ In France, then, while an artist theoretically cannot waive or assign his moral rights, ${ }^{57}$ French courts will enforce contracts that allow alterations which are consistent with the spirit of the work. ${ }^{58}$ French courts, however, will void contracts proposing alterations that threaten to modify the work unreasonably. ${ }^{59}$ Under the French view of alienability and integrity, even if Serra had contractually granted the GSA the right to remove "Tilted Arc" from the plaza, that provision would have been void because the alteration of the context would be considered an unreasonable alteration.

While an artist holds broad powers in a country which recognizes moral rights, these powers do not endure perpetually. In 1971, article $6 b i s$ of the Berne Convention was amended to recognize the artist's moral rights following her death for a period at least coextensive with the duration of her economic rights. ${ }^{60}$ Member states whose national legislation does not posthumously protect all the moral rights described in article 6bis (1) at the time they adopt the convention may permit some of

51. Shostakovich v. Twentieth Century Fox Film Corp., 196 Misc. 67, 70, 80 N.Y.S.2d 575, 578 (Sup. Ct. 1948), aff'd, 275 A.D. 692, 87 N.Y.S.2d 430 (App. Div. 1949) (noting that the very existence of a moral right was unclear, and that even if there were such a right, the court would not apply it to the facts before it).

52. See Jan. 13, 1953, Cour d'appel, Paris, 1954 D. Jur. 16, 80.

53. See Kwall, supra note 33 , at 28 .

54. Id. at 12 n.45.

55. Id. at 12.

56. See Merryman, supra note 28, at 1044; see also Nimmer, supra note 37, at 524 (noting that article 6 bis leaves the issue of alienability to members' national legislation).

57. Kwall, supra note 33 , at $12-13$.

58. Amarnick, supra note 33 , at $47-48$.

59. See Merryman, supra note 28 , at 1045.

60. Berne Convention, supra note 38 , art. 6 bis (2). 
those rights to cease at death. ${ }^{61}$ Since the United States does not currently offer special protection for moral rights, it would not be required to extend protection to the artist posthuniously. A nuniber of countries, including West Germany, follow the general Berne approach that moral rights are protected for the same duration as the artist's economic rights; others adhere to the French view that inoral rights are perpetual. ${ }^{62}$ The posthumous continuance of inoral rights may be justified as necessary to protect the artist's reputation, which hives on after her death. Moreover, society's interest in preserving the integrity of its cultural heritage requires the protection of the artist's original contributions. Many countries therefore vest moral rights in the family of the deceased artist, while other nations entrust posthumous inoral rights to a governmental body m order to safeguard this societal interest. ${ }^{63}$

II

\section{Berne IMPlementation Debate: Adequacy OF CURRENT Protections of Moral Rights in THE UNITED STATES}

On March 1, 1989, the Umited States became a meinber of the Berne Convention, ${ }^{64}$ which recognizes the moral rights of paternity and integrity. ${ }^{65}$ Prior to U.S. adherence to Berne, no United States court had recognized inoral rights. Rather, American courts have explicitly rejected the doctrine. ${ }^{66}$ Courts seeking to protect an artist's personality interests have had to rely upon other legal theories. Whether these substitute theories sufficiently protect the artist's patermity and integrity interests has becoine an important subject of the debate over American adherence to Berne. This Part will evaluate the current American scheine of protections, arguing that it is inadequate to fully protect artists' moral rights.

The Berne Convention is the primary international treaty ensuring global copyright protection. ${ }^{67}$ The treaty was concluded in $1886^{68}$ with a

61. Id.; see also Kwall, supra note 33, at $14 \&$ n.54 (discussing the duration of moral rights on a posthuinous basis).

62. Kwall, supra note 33 , at 15 .

63. Id. at 16 .

64. Berne Convention Implementation Act of 1988, Pub. L. No. 100-568, 102 Stat. 2853.

65. See supra notes 38-39 and accompanying text.

66. See, e.g., Vargas v. Esquire, Inc., 164 F.2d 522, 526 (7th Cir. 1947) (refusing to recognize "so-called moral rights"); Shostakovich v. Twentieth Century-Fox Film Corp., 196 Misc. 67, 70-71, 80 N.Y.S.2d 575, 578-79 (Sup. Ct. 1948), aff'd, 275 A.D. 692, 87 N.Y.S.2d 430 (App. Div. 1949); Crimi v. Rutgers Presbyterian Church, 194 Misc. 570, 575-76, 89 N.Y.S.2d 813, 818-19 (1949) (moral rights doctrine "has not yet received acceptance").

67. Note, Internationalizing the Copyright Code: An Analysis of Legislative Proposals Seeking Adherence to the Berne Convention, 76 GEo. L.J. 467, 467-68 (1987) (authored by Doriane Lambelet).

68. House COMM. ON Judiciary, Berne CONVENTION IMPLEMENTATION ACT OF 1988, H.R. REP. No. 100-609, 100th Cong., 2d Sess. 11 (1988) [hereinafter BERNE REPORT]. 
goal of developing copyright laws favorable to authors in all civilized countries. ${ }^{69}$ Seventy-seven nations currently adhere to the treaty; the Soviet Union and the People's Republic of China remain holdouts. ${ }^{70}$

As the 100th anniversary of the Berne Convention approached, heightened interest in United States' accession to the treaty spurred the State Department's creation of an Ad Hoc Working Group to study accession prospects. This interest was also manifested in the Senate Judiciary Subcoinmittee on Patents, Copyrights and Trademarks, which held two days of hearings on the issue. ${ }^{71}$ In addition to procuring the benefits of international copyright protection, Congress viewed adherence to the Berne Convention as a means of establishing new multilateral relationships and as a step towards the overall reform of trade law. ${ }^{72}$ The inadequacy of current international agreements, the problem of intellectual property piracy, the limited protection offered to Berne nonmembers, and perceived threats of retaliatory action by Berne members all combined to prompt renewed consideration of Berne ratification. ${ }^{73}$ One commentator has suggested that the United States' interest in ensuring that the next revision of Berne does not facilitate easier access to works of authorship on the part of developing nations impelled American adherence to the Convention. ${ }^{74}$

Among the proponents of adherence to Berne, two positions emerged. One position, the "minimalist" view, posited that no new federal moral rights legislation was needed: existing protections of the rights of paternity and integrity were sufficient to permit good faith American accession to Berne. The other position found existing protections of personality interests insufficient and argued for specific federal recognition of moral rights, irrespective of the possibility of accession without increased federal protections. ${ }^{75}$

The minimalist view thus asserts that the composite of current protections suffices to protect moral rights. Commentators have extensively criticized this position. ${ }^{76}$ Yet Congress justified the minimalist view as

69. Id. at 11-12. Other goals the committee cites are the elimination of basing authors' rights on reciprocity, ending discrimination in rights between domestic and foreign-born authors, the abolition of formalities for the recognition and protection of copyright in foreign works, and the promotion of uniform international legislation protecting authors. Id.

70. Note, supra note 67 , at 468 .

71. BERNE REPORT, supra note 68 , at 7-8.

72. See id. at 7 ("U.S. membership in the Berne Union is a part in the larger picture of reform of our trade laws").

73. See Note, supra note 67 , at $468-69$.

74. See Brown, Adherence to the Berne Copyright Convention: The Moral Rights Issue, $35 \mathrm{~J}$. COPYRIGHT SOC'Y U.S.A. 196, 198 (1988).

75. See id. at 200-05.

76. See, e.g., id.; Damich, Moral Rights in the United States and Article 6 bis of the Berne Convention: A Comment on the Preliminary Report of the Ad Hoc Working Group on U.S. Adherence to the Berne Convention, 10 CoLUM.-VLA J.L. \& ARTS 655 (1986). See generally Kwall, supra note 
the most efficient means of accomplishing the "paramount" but limited goal of compliance with the provisions of Berne. ${ }^{77}$ Moreover, article 6 bis (1) describes the paternity and integrity rights in general terms; ${ }^{78}$ therefore, the substance of moral rights in a particular country would seem to be determinable by domestic legislation. Such a reading is reinforced by the terms of article 6 bis (3), which provides that national legislation shall determine the means of protecting moral rights. ${ }^{79}$ Thus, although a member nation may not blithely ignore the substance of article 6 bis, that nation's legislature may determine how liberally it will construe the provisions. ${ }^{80}$ As Professor Nimmer concluded in 1967, "It could be said that the United States does comply with a narrow construction of the requirements of article 6 bis." $" 81$

"Minimalism" in fact prevailed in Congress, and the United States joined the Berne Convention without creating any additional moral rights legislation. The Judiciary Committee of the House of Representatives cited the assurances of witnesses at the hearmgs it held, the experts at the Roundtable discussions of the World Intellectual Property Organization (WIPO), ${ }^{82}$ French officials, and the Director General of WIPO to support its position that no additional moral rights legislation would be necessary to comply with Berne. ${ }^{83}$ Moreover, the Berne Implementation Act ${ }^{84}$ and its legislative history go to great lengths to emphasize that the legislation is "neutral" on the moral rights issue. ${ }^{85}$

The Berne Implementation Act underscores the consensus that Berne is an executory treaty rather than a self-executing one. ${ }^{86}$ As such,

33; Merryman, supra note 28; Note, Artists' Rights in the United States: Toward Federal Legislation, 25 HARV. J. ON LEGIS. 153 (1988) (authored by Michael Horowitz).

77. See BERNE REPORT, supra note 68 , at 20.

78. See Nimmer, supra note 37 , at 522 .

79. See id.; see also supra notes 38-39 and accompanying text.

80. Nimmer, supra note 37 , at 522.

81. Id.

82. WIPO is the United Nations agency which administers compliance with Berne. BERNE REPORT, supra note 68, at 13 .

83. Id. at 36-37.

84. Berne Convention Implementation Act of 1988, Pub. L. No. 100-568, 102 Stat. 2853.

85. BERNE REPORT, supra note 68, at 38-39 ("Since the Committee finds that existing law is sufficient to enable the United States to adhere to the Berne Convention, the implementing legislation is completely neutral on the issue of whether and how protection of the rights of paternity and integrity should develop in the future.") (emphasis deleted).

86. Id. at 38; Note, supra note 67 , at 479 . In 1829 Chief Justice John Marshall articulated the difference between an executory treaty and a self-executing one when he wrote:

Our constitution declares a treaty to be the law of the land. It is, consequently, to be regarded in courts of justice as equivalent to an act of the legislature, whenever it operates of itself without the aid of any legislative provision. But when the terms of the stipulation import a contract, when either of the parties engages to perform a particular act, the treaty addresses itself to the political, not the judicial department; and the legislature must execute the contract before it can become a rule for the Court.

M. Janis, AN Introduction to International LAW 74 (1988) (quoting Foster \& Elam v. 
causes of action can arise only from the implementing legislation and not from the treaty itself. ${ }^{87}$ The Act accordingly states in section $2(1)$ that Berne is not self-executing, ${ }^{88}$ and in section 2(2) that American obligations under Berne "may be performed only pursuant to appropriate domestic law." 89 Section 2(3) declares that only those rights and interests arising under the Berne Implementation acting together with existing law may be claimed to satisfy the obligations of adherence. ${ }^{90}$ Thus, as the legislative history stresses, the Act is intended to be "absolutely neutral on the issue of the rights of paternity and integrity." 11 That is, "adherence to Berne will have no effect whatsoever on the state of moral rights protections in this country."92 This avowed intention is reinforced by section $3(\mathrm{~b})$ which provides that any claim by an artist based on the rights of integrity or paternity is not expanded or reduced by adherence to Berne..$^{93}$

Moreover, the Berne Implementation Act further provides in other subsections that the provisions of the treaty itself cannot be used in a moral rights action. Sections 3(a)(2) and 4(a)(3), both of which essentially provide that no actions can be brought on the provisions of the Berne Convention itself, are "intended to assure United States courts that adherence to Berne is not, of itself, a basis for any cause of action."94 Finally, to insure that courts understand the ramifications of "minimalism," the legislative history adds a further caveat: "To the extent that courts, in interpreting our domestic laws, properly look to the laws of foreign countries, they may continue to do so. The fact of Berne adherence will not enable them to look to such laws to any greater or lesser degree." 95

The Berne Implementation Act and its legislative history foreclose any cause of action to vindicate moral rights other than actions arising under existing substitute theories of protection. As Richard Serra and his attorneys came to realize, adherence to Berne provides no additional protection of paternity or integrity rights for visual artists. It is likely

Neilson, 27 U.S. (2 Pet.) 253, 314 (1829) (Marshall, C.J.)). Since Berne engages member nations to perform the act of protecting moral rights, it is arguably executory, requiring an act of Congress to create relief for an artist.

87. Note, supra note 67 , at 479 .

88. Berne Convention Implementation Act of 1988, Pub. L. No. 100-568, § 2(1), 102 Stat. $2853,2853$.

89. Id. § 2(2).

90. Id. $\S 2(3)$.

91. BERne RePORT, supra note 68 , at 38.

92. Id.

93. Berne Convention Implementation Act of $1988 \S 3$ (b).

94. BERNE REPORT, supra note 68, at 39; see also Berne Convention Implementation Act of $1988 \S \S 3(\mathrm{a})(2), 4(\mathrm{a})(3)$.

95. Id. 
that Judge Patterson, who issued the temporary restraining order that briefly postponed the removal of "Tilted Arc," would have come to the same realization after closer examination of the Berne Implementation Act and its legislative history. Yet Serra's defeat may serve as a catalyst for federal legislation. The destruction of the "Arc" starkly dramatizes the absence of substantive protection for visual artists in the United States, and particularly for site-specific artists of publicly commissioned works. While "minimalism" may have been sufficient to achieve United States adherence to Berne, it is imsufficient to protect the personality rights of artists as intended by the spirit of Berne. As the following Sections will illustrate, the minimalist position relies on protections that are makeshift, inelegant, and, ultimately, conjectural.

\section{A. Copyright Protection of Moral Rights}

The 1976 Copyright Act ${ }^{96}$ does not explicitly safeguard the personal rights of artists. Rather, the Act protects the pecuniary rights of the copyright owner. ${ }^{97}$ The Act guarantees the copyright owner the exclusive rights to copy and distribute the original work, to prepare derivative works, and to display the work publicly ${ }^{98}$-rights primarily of economic value. Yet this protection of economic interests often dovetails into the safeguarding of moral rights. ${ }^{99}$ When an artist is also the copyright owner, she can invoke the copyright laws to protect, to some degree, her rights of paternity and integrity. ${ }^{100}$

96. 17 U.S.C. $\$ \S 101-810$ (1988).

97. See Kwall, supra note 33, at 2.

98. Section 106 conveys "exclusive rights to do and to authorize any of the following":

(1) to reproduce the copyrighted work in copies or phonorecords;

(2) to prepare derivative works based upon the copyrighted work;

(3) to distribute copies or phonorecords of the copyrighted work to the public by sale or other transfer of ownership, or by rental, lease or lending;

(4) in the case of literary, musical, dramatic, and choreographic works, pantomimes, and motion pictures and other audiovisual works, to perform the copyrighted work publicly; and

(5) in the case of literary, musical, dramatic, and choreographic works, pantomimes, and pictorial, graphic, or sculptural works, including the individual images of a motion picture or other audiovisual work, to display the copyrighted work publicly.

17 U.S.C. $\S 106$ (1988).

99. One commentator has noted:

[T] he economic incentive for the creation and dissemination of artistic work which is furnished by copyright protection is threatened to the extent that the artist is unable to control the manner in which his work is displayed to the public upon which he is financially dependent. In this sense, then, an artist's "moral right" protects both his personal interest in preserving his own artistic integrity and his economic interest in maintaining his artistic reputation and thereby the long-run marketability of his work. ... [V]indication of this moral right ... is consistent with the policies and objectives sought to be advanced by [copyright] laws . . . .

Comment, Protection of Artistic Integrity: Gilliam v. American Broadcasting Companies, 90 HARv. L. REV. 473, 477 (1976) (footnotes omitted).

100. See generally Kwall, supra note 33 (discussing the application of copyright laws to moral rights). 
Until recently, however, an artist rarely was able to retain copyright in her work after the work was sold, so copyright laws afforded artists no real protection of any kind. The common law presumed that the transfer of a physical work of art included the conveyance of the common law copyright therein unless the artist retained her copyright by contract. ${ }^{101}$ The Copyright Act of 1976 reversed that presumption. The current section 202 thereunder provides that copyright is "distinct from ownership of any material object in which the work is embodied." ${ }^{102}$ Together with section 204(a), which provides that copyright ownership interests may only be transferred by a signed written instrument or by operation of law, ${ }^{103}$ section 202 enables artists to retain copyright in a sold artwork much more easily.

\section{An Artist's Retention of Copyright}

The Copyright Act affords a copyright owner economic protections that may incidentally protect moral rights. Yet before an artist can benefit from copyright protection, she must own the copyright. This Subsection will examine some of the difficulties artists encounter when seeking to retain the benefits of copyright, and some of the methods which the Act offers to protect artists.

\section{a. The Work-for-Hire Doctrine}

Despite the Copyright Act's separation of copyright from ownership of the object, many artists have been confronted by a nearly insurmountable problem: the work-for-hire doctrine embodied in section 201(b) of the Act. ${ }^{104}$ Under the terms of that section, when a work is "for hire," the "person for whom the work was prepared is considered the author" and therefore the holder of the copyright, unless "expressly agreed otherwise" in writing. ${ }^{105}$ Many artists, particularly those in broadcasting, filmmaking, and journalism, as well as visual artists who create works under commission, including site-specific artists like Richard Serra, have worked primarily "for hire." 106 While section 202 would grant these artists copyrights in their work, section 201(b) takes the copyrights away.

Numerous commentators have complained about the quagmire resulting from judicial interpretations of the poorly drafted and inequita-

101. See, e.g., Pushman v. New York Graphic Soc'y, Inc., 287 N.Y. 302, 39 N.E.2d 249 (1942) (affirming the dismissal of an action brought by an artist to enjoin the reproduction of his uncopyrighted painting).

102. 17 U.S.C. $\$ 202$ (1988).

103. Id. $\S 204(\mathrm{a})$.

104. Id. $\S 201(\mathrm{~b})$.

105. Id.

106. See Brown, supra note 74 , at 207 ; Note, supra note 76 , at 175 (referring to scriptwriters). 
ble work-for-hire section. ${ }^{107}$ The section alternatively defines a "work made for hire" as:

(1) a work prepared by an employee within the scope of his or her employment; or

(2) a work specially ordered or commissioned for use as a contribution to a collective work, as a part of a motion picture or other audiovisual work, as a translation, as a supplementary work, as a compilation, as an instructional text, as a test, as answer material for a test, or as an atlas, if the parties expressly agree in a written instrument signed by them that the work shall be considered a work made for hire. ${ }^{108}$

Several judicial interpretations of the work-for-hire provisions evolved. ${ }^{109}$ The controlling view had been expounded in Aldon Accessories Ltd. v. Spiegel, Inc. ${ }^{110}$ which held that section 201(b) was not intended to alter prior law. As a result, the court found that "employees" whose prepared works constituted "works for hire" included any "[independent] contractors who were actually sufficiently supervised and directed by the hiring party."111 Thus, under the rule of Aldon Accessories, the commissioner was sole owner of the copyright if he had the requisite supervision and control over the creation of the artwork. ${ }^{112}$ Without such supervision, the independent contractor would be sole author and copyright owner unless otherwise expressly agreed. ${ }^{113}$

The Supreme Court rejected the Aldon Accessories "sufficient supervision" test in Community for Creative Non-Violence v. Reid, ${ }^{14}$ which submitted section 101 to a literal interpretation. Accordingly, a court must "first . . . ascertain, using principles of general common law of agency, whether the work was prepared by an employee or an independent contractor. [Then,] the court can apply the appropriate subsection of

107. See, e.g., Brown, supra note 74, at 207-08; Fidlow, The "Works Made for Hire" Doctrine and the Employee/Independent Contractor Dichotomy: The Need for Congressional Clarification, 10 HASTINGS Comm/ENr L.J. 591, 591-93 (1988); Hardy, Copyright Law's Concept of Employment, 35 J. CoPYRIGHT SOC'Y U.S.A. 210, 210-21 (1988); Ossola, Work for Hire: A Judicial Quagmire and a Legislative Solution, 17 J. ARTS MGMT. \& L. 23, 26-27 (1987); Comment, The Creative Commissioner: Commissioned Works under the Copyright Act of 1976, 62 N.Y.U. L. REv. 373, 38693 (1987) (authored by Robert Penchina); Comment, Commissioned Works as Works Made for Hire Under the 1976 Copyright Act: Misinterpretation and Injustice, 135 U. PA. L. REV. 1281, 1296-1306 (1987) (authored by Marci A. Hamilton).

108. 17 U.S.C. § 101 (1988).

109. See Easter Seal Soc'y v. Playboy Enters., 815 F.2d 323, 327-34 (5th Cir. 1987) (discussing the different interpretations that had evolved in the circuit courts after the adoption of the work-forhire language of section 201(b)), cert. denied, 485 U.S. 981 (1988).

110. 738 F.2d 548 (2d Cir. 1984), cert. denied, 469 U.S. 982 (1984).

111. Id. at 552 .

112. Community for Creative Non-Violence v. Reid, 846 F.2d 1485, 1490 (D.C. Cir. 1988), aff'd, 109 S. Ct. 2166 (1989).

113. See supra text accompanying notes $96-103$.

114. 109 S. Ct. 2166 (1989). 
$\S 101 . " 115$ Section 101(2) applies to those artists found to be independent contractors. Thus, "[a]11 works by independent contractors . . . are not works for hire unless the work comes within the nine narrow statutory categories and parties agree in a signed instrument."116

After Reid, visual artists of commissioned works who retain independent-contractor status will not be deemed employees for hire since section 101(2) does not apply to pictorial, graphic, and sculptural works. But courts applying the Aldon Accessories rule deemed many commissioned artworks to be works for hire, thus preventing the artists of those works from claiming the exclusive rights of copyright ownership.

Moreover, the provisions of section 204(a) still provide that an artist can contract away her copyright in a work by executing a written instrument. Given the unequal bargaining positions between an artist and a commissioner of art, commissioning contracts will often provide for transfer of copyrights to the commissioner. Thus, even after Reid, commissioners can restrict their dealings to those artists who are willing to forgo independent contractor status and their copyrights.

\section{b. The Possibility of Joint Authorship}

Even if a commissioned artist is an independent contractor, she may not be sole owner of the copyright. The District of Columbia Circuit Court in Reid cautioned that the work's commissioner might be found to be a joint author of the work with the artist. ${ }^{117} \mathrm{~A}$ finding that he is a joint author gives the commissioner the same rights as the artist and thus allows the commissioner to undercut many of the protections offered by the Copyright Act. ${ }^{18}$

The Copyright Act of 1976 defines a joint work as one "prepared by two or more authors with the intention that their contributions be merged into inseparable or interdependent parts of a unitary whole." 119 While each author must make more than de minimus contributions to the work, one may nevertheless qualify as a joint author even if his contribution to the collaboration "standing alone would not be copyrightable." ${ }^{20}$ Both authors' expression of original authorship must be fixed in

115. Id. at 2178.

116. Easter Seal Soc'y v. Playboy Enters., 815 F.2d 323, 329 (5th Cir. 1987) (stating the "literal interpretation" test that later was adopted in Reid) (emphasis in original).

117. Reid, 846 F.2d at $1495-98$.

118. Joint authors may each use the copyright independently. W. PATRY, LATMAN's ThE COPYRIGHT LAW 116-17 (6th ed. 1986).

119. 17 U.S.C. § 101 (1988).

120. 1 M. Nimmer \& D. Nimmer, Nimmer on CopyriGht § 6.07, at 6.18 (1989). See generally, Note, Joint Authorship of Commissioned Works, 89 CoLUM. L. REv. 867 (1989) (authored by Julie Katzman). 
a tangible medium. ${ }^{121}$

Joint authorship determinations clearly will depend upon the record in each case. In the Serra case, it would seem unjust to allow the United States to claim a collaborative contribution, and thus control over the copyright, given the Government's aesthetic rejection of the work. Nevertheless, if the court had determined that the Government and Serra intended the contributions to be merged, the court would have held the Federal Government to be a co-author of the work, if it did not hold the Government to be the sole author of a work for hire.

\section{c. The First-Sale Doctrine}

The possibility of artist-commissioner joint authority raises thorny problems under the first-sale doctrine. This doctrine, codified in section 109 of the 1976 Act, is the most serious impediment to copyright protection for the moral rights of site-specific artists and other creators of singular works of art. ${ }^{122}$ Under section 109, the copyright owner's exclusive right under section 106(3) to distribute copies of the work is sharply curtailed. Her right to sell a copy of the artwork extends only to her first sale of the copy; thereafter, she relinquishes control over the subsequent sales of that copy. ${ }^{123}$ In addition, section 109 (c) linits the display rights of the copyright owner under section $106(5) .^{124}$ The owner of a copy, including the only extant copy, may display it publicly without authorization of the copyright owner. ${ }^{125}$

The D.C. Circuit in Community for Creative Non-Violence v. Reid recognized the dilemina that results from the first-sale doctrine when there is only one extant copy. ${ }^{126}$ Although the artist in Reid may have held the copyright jointly with the commissioner, the coinmissioner solely owned the singular copy and could control its display. ${ }^{127}$

121. 17 U.S.C. $\S 102$ (1988). See, e.g., Meltzer v. Zoller, 520 F. Supp. 847,857 (D.N.J. 1981) (ideas and sketches incorporated into architectural plans did not constitute "fixed expressions of ideas" by prospective joint author).

122. 17 U.S.C. $\S 109$ (1988). Section 109 provides in part:

(a) Notwithstanding the provisions of section $106(3)$, the owner of a particular copy ... or any person authorized by such owner, is entitled, without the authority of the copyright owner, to sell or otherwise dispose of the possession of that copy. . . .

(c) Notwithstanding the provisions of section 106(5), the owner of a particular copy ... or any person authorized by such owner, is entitled, without the authority of the copyright owner, to display that copy publicly ....

123. See American Int'l Pictures v. Foreman, 576 F.2d 661, 664 (5th Cir. 1978).

124. 17 U.S.C. $\S 109$ (c) (1988). Without the provisions of section $109(\mathrm{c})$, section $106(5)$ grants the artist, as the sole owner of the copyright, the exclusive right to display her copyrighted work publicly. 17 U.S.C. $\S 106(5)$.

125. 17 U.S.C. $\S 109$ (c) (1988).

126. Community for Creative Non-Violence v. Reid, 846 F.2d 1485, 1498 (D.C. Cir. 1988), aff'd, 109 S. Ct. 2166 (1989).

127. Id. 
Commissioned artists of site-specific work who object to the context of the artwork's display may have no recourse, then, with or without copyright ownership. ${ }^{128}$ As an equal owner of the copyright, a joint author also has the power to sell his ownership interest, thereby transferring coownership of important rights to a stranger. The effect of such a sale by a work's commissioner may have dramatic consequences on an artist's ability to control the context in which her work is displayed.

\section{d. Protection of the Artist as a "Beneficial Owner" of the Copyright}

An Artist might find protection for her moral rights through section 501(b) of the 1976 Act. That section provides that the "legal or beneficial owner of an exclusive right under a copyright is entitled . . . to institute an action for any infringement of that particular right committed while he or she is the owner of it."129 The legislative history of the Act states that '[a] 'beneficial owner' for this purpose would include, for example, an author who had parted with legal title to the copyright in exchange for percentage royalties based on sales or license fees." 130 Arguably, all artists who have transferred their copyrights should be considered beneficial owners, regardless of whether they receive royalties. This view is consistent with the legislative history, which refers to an artist who has exchanged copyright for royalties as only one example of a beneficial owner. There is no principled difference between exchange of a work for royalties and exchange of a work for cash. ${ }^{131}$

This argument goes against the grain of copyright protection, however, which is intended to protect only pecuniary interests. Artists without copyright or royalty rights maintain no economic ties to the work. Nevertheless, actions affecting personality rights do implicate the artist's reputation, and hence some future economic interests as well. ${ }^{132}$ Such a broad reading of the economic implications of moral rights violations could lead to a construction of section 501(b) that protects all artists as beneficial copyright owners in the future, although the prospect seems remote.

128. See supra notes $50-53$ and accompanying text (discussing the lack of moral rights protections offered to site-specific artists who object to the context in which their work is displayed).

129. 17 U.S.C. $\$ 501$ (b) (1988).

130. See H.R. REP. No. 1476, 94th Cong., 2d Sess. 159, reprinted in 1976 U.S. CodE CoNG. \& ADMIN. News 5659, 5775. Courts have so held. See, e.g., Cortner v. Israel, 732 F.2d 267, 271 (2d Cir. 1984) (composer who assigned copyright title to a publisher in exchange for royalties had standing to sue for infringement); Kamakazi Music Corp. v. Robbins Music Corp., 534 F. Supp. 69, 74 (S.D.N.Y. 1982) (transferor of legal title to copyrights in exchange for royalties is a beneficial owner of the copyright).

131. See Kwall, supra note 33, at 49-55.

132. See supra note 99. 


\section{e. The Artist's Right to Terminate a Grant of Copyright}

The termination provisions of sections $203^{133}$ and 304(c) ${ }^{134}$ suggest that artists without copyright or royalty rights in their work still retain some economic and beneficial interest in the copyright. ${ }^{135}$ Section 203 provides that an author, except an author of a work for hire, ${ }^{136}$ may terminate the grant of any copyright or right under a copyright "at any time during a period of five years beginming at the end of thirty-five years from the date of execution of the grant," 137 as long as she complies with the notice provisions. ${ }^{138}$ Section 304(c) is a similar provision for copyrights subsisting as of 1976 . These sections were intended to protect artists from unremunerative transfers and were deemed to be necessary "because of the unequal bargaiming position of authors." 139 Congress believed that the artist, as "fundamental beneficiary of copyright," should be empowered to share in the constitutionally provided property right. ${ }^{140}$ Thus an artist who has neither copyright nor royalty right still retains an interest in the copyright. It has even been suggested that section 203 implicitly empowers an artist to terminate her grant of copyright if the owner has violated her moral rights. ${ }^{141}$ This position is consistent with the observation that incursions upon personal rights harm a work's future marketability. ${ }^{142}$

\section{Using Copyright to Protect Moral Rights}

If an artist is able to retain the benefits of the Copyright Act, the artist can then rely upon the Act to provide certain protections of her moral rights. This Subsection will examine how the Copyright Act protects moral rights and some of the significant ways in which the Act fails to do so.

\section{a. The Problem of Destruction}

After grappling with the issue for some time, the European courts have recently determined that the artist's integrity and paternity interests preclude the owner of an artistic work from destroying it against the

133. 17 US.C. $\S 203$ (1988).

134. Id. §304(c).

135. See Kwall, supra note 33 , at 49-55.

136. 17 U.S.C. § 203(a) (1988).

137. Id. § 203(a)(3).

138. See id. $\$ 203(\mathrm{a})(4)$.

139. H.R. REP. No. 1476 , supra note 130 , at 5740 .

140. Id. at 5756.

141. See Comment, Copyright: Moral Right-A Proposal, 43 Fordham L. Rev. 793, 810 (1975) (authored by Joseph B. Valentine).

142. See supra note 99 and accompanying text; text accompanying note 132. 
artist's wishes. ${ }^{143}$ Under the United States' Copyright Act of 1976, however, the section 109 language allowing an owner to "sell or otherwise dispose of" a copy disturbs artists, especially site-specific artists. ${ }^{144}$ The legislative history of the 1976 Act suggests that the copyright owner cannot prevent the owner of a "copy" from destroying it. ${ }^{145}$ This is particularly troubling to the creator of singular artworks because section 101 defines "copies" as "includ[ing] the material object ... . in which the work is first fixed." 146

Therefore, the GSA's intact removal of "Tilted Arc" to a new site, if deemed a destruction of the singular copy, may not have been preventable under copyright law even if Serra had managed to retain the copyright. "It's a lawless law, akin to book burning," Serra coinplained. "It's even worse than book-burning because there are other copies of a destroyed book and only one of each of my sculptures."147 As noted above, there is some question whether a work is "destroyed" by being removed and placed $\mathrm{m}$ an offensive location, ${ }^{148}$ although the inoving of the portable elements of a site-specific work is arguably itself an act of destruction, irrespective of the new location's offensiveness. The implications become important when the "otherwise dispose of" language of section 109(a) comes into play, for if the work is "destroyed," the artist has no recourse under section 106. If, as seems more likely, the work has merely been "altered," the artist retaining copyright may have some remedy for any harm to her integrity rights. ${ }^{149}$

\section{b. The Right to Prevent Alterations}

Under United States law, a creator retaining copyright has a better chance of vindicating her integrity interests in cases of alteration than in cases of destruction. Gilliam v. American Broadcasting Cos. ${ }^{150}$ granted rehef to comedy-group Monty Python, whose scripts had been produced on British television but were edited extensively prior to being shown on Ainerican television. The court held that defendant Ainerican Broadcasting Companies' (ABC) editing, if proven to violate the license agreement, constituted copyright infringement. ${ }^{51}$ The court reasoned that because the contract between Monty Python and the British

143. See supra note 45 and accompanying text.

144. 17 U.S.C. $\$ 109$ (a) (1988) (the owner of a copy may "sell or otherwise dispose" of that copy without the consent of the copyright owner).

145. H.R. REP. No. 1476, suprá note 130, at 5693.

146. 17 U.S.C. $\$ 101$ (1988).

147. San Francisco Chron., Mar. 17, 1989, at E3, col. 1.

148. See supra text accompanying notes 50-53.

149. See infra notes $150-60$ and accompanying text.

150. 538 F.2d 14 (2d Cir. 1976).

151. Id. at 21 . 
Broadcasting Coinpany (BBC), ABC's licensor, did not expressly grant $\mathrm{BBC}$ the right to edit the recorded programs, $\mathrm{BBC}$ could not grant that right to $\mathrm{ABC}{ }^{152}$ Since plaimtiff was a copyright owner of the original scripts, Gilliam's "ultimate moral right significance may be that in the face of a silent contract, an artist will not be held to have granted his hicensee the right to perform extensive editing."153

Five years later, WGN Continental Broadcasting Co. v. United Video, Inc. ${ }^{154}$ approved the Gilliam holding and extended it. The defendant, a telecommurnications common carrier, reinoved teletext encoded in plaintiff's copyrighted news program prior to transmission. ${ }^{155}$ The court held that defendant's deletion of the teletext constituted copyright infrimgernent as an alteration of the copyrighted work, relying solely upon Gilliam. ${ }^{156}$ Yet WGN's equation of deletion with infrimgement extended Gilliam. ${ }^{157}$ Gilliam held that "unauthorized changes in the work which are so extensive as to impair the integrity of the original work constitute copyright infrimgement," 158 whereas $W G N$ held that any material deletion - that is, a nontrivial change which need not impair the integrity of the work-constitutes infringement. ${ }^{159}$

$W G N$ 's deletion-as-infringement rule might be used to protect moral rights by artists who have retained exclusive rights under their copyrights. ${ }^{160}$ For exanple, if Serra had retained copyright in "Tilted Arc," he might have been able to prevent the Federal Government from removing nontrivial quantities of shrubbery froin the Federal Plaza if such removal would have altered the site. In this fashion, the $W G N$ rule could be apphied to preserve the artist's integrity right.

\section{c. Protection Against Derivative Works}

Section 106(2) of the Copyright Act grants the copyright owner the exclusive right to prepare "derivative works based upon the copyrighted

152. Id.

153. Kwall, supra note 33, at 35; cf. Note, The Monty Python Litigation-Of Moral Right and the Lanham Act, 125 U. PA. L. REv, 611, 628-33 (1977) (arguing that Gilliam held that when the contract is silent, extensive editing infringes on the integrity interest, except that minimal editing required for presentation is allowed). But cf. Comment, Monty Python and the Lanham Act: In Search of the Moral Right, 30 RuTGERS L. REv. 452, 473 (1977) (arguing that "[g]enerally, courts have presumed that what creative control an artist has not specifically reserved is waived") (authored by Susan L. Solomon).

154. 693 F.2d 622 (7th Cir. 1982).

155. Id. at 624 .

156. Id, at 625 .

157. Barnett, From New Technology to Moral Rights: Passive Carriers, Teletext, and Deletion as Copyright Infringement-The WGN Case, 31 J. CoPYRIGHT Soc'x U.S.A. 427, 438-41 (1984).

158. 2 M. NimMER \& D. NIMMER, supra note $27, \S 8.21$ [C][1], at 8-259 to 8-260.

159. Barnett, supra note 157 , at $439-40$.

160. See Kwall, supra note 33 , at $36-37$. 
work."161 The Act defines a derivative work as one that "represent[s] an original work of authorship" but is "based upon one or more preexisting works" and that "recast[s], transform[s], or adapt[s]" the preexisting work. ${ }^{162}$ Since a derivative work must thus itself be copyrightable, the author of the derivative work must contribute the modicum of "originality" necessary to achieve a copyright; ${ }^{163}$ if the putative derivative work is a "distinguishable variation"164 or "substantial variation"165 from the preexisting work, the requisite originality will be found to exist. ${ }^{166}$

When unauthorized alterations and modifications of a work would result in an unauthorized derivative work, an artist retaining copyright may prevent such action through section $106(2){ }^{167}$ Similarly, if an artist assigns the right to prepare a derivative work and allows her name to be associated with the work, the Gilliam rationale would require that a new work billed as "based upon" the underlying work may not contain changes that would constitute mutilation. ${ }^{168}$ Alternatively, a court could find that even though an artist granted certain rights, such as the right of reproduction, she did not grant other derivative rights. ${ }^{169}$ If the work is altered beyond recognition but not attributed to the artist, her rights under 106(2) are not infringed and her right of integrity has not been protected, ${ }^{170}$ although incidentally her paternity right has been.

If a site-specific artist retains exclusive derivative rights under section 106(2), both the terms of the section and the decisions applying its principles protect the artist's right to integrity. Alterations that mutilatc the work should be found to constitute unauthorized derivative works, and should thus be compensated for or barred. Applying this reasoning, the removal or relocation of a site-specific work similarly might be found to constitute an unauthorized derivative work if the relocation is found to be sufficiently original. While L. Batlin \& Son $v$. Snyder ${ }^{171}$ required that the process of creating the new work involve sufficient originality to con-

161. 17 U.S.C. $\$ 106(2)$ (1988).

162. Id. $\S 101$.

163. Id. § 102; Goldstein, Derivative Rights and Derivative Works in Copyright, $30 \mathrm{~J}$. COPYRIGHT SOC'Y U.S.A. 209, 215-18, 240-43 (1983).

164. Alfred Bell v. Catalda Fine Arts, Inc., 191 F.2d 99, 102 (2d Cir. 1951) (holding that mezzotint reproductions of old masters were sufficiently original because they were distinguishable variations).

165. L. Batlin \& Son v. Snyder, 536 F.2d 486, 490-91 (2d Cir. 1976) (holding that the plastic reproduction of a metal coin bank failed the originality test because it contained merely trivial variations rather than substantial variations).

166. Barnett, supra note 157 , at 467.

167. See Kwall, supra note 33, at 40-41; 2 M. Nimmer \& D. NimmER, supra note $27, \S 8.09$ [A], at 8-114 to 8-119.

168. See Kwall, supra note 33 , at $40-41$.

169. See 2 M. NiMMER \& D. NimMER, supra note $27, \S 8.21$ [C][1], at 8-261.

170. Kwall, supra note 33 , at 63 .

171. 536 F.2d 486 (2d Cir. 1976). 
stitute a derivative work, ${ }^{172}$ "no reason appears not to apply the rule that 'distinguishable variation' is itself the test of originality." 173

In the case of site-specific art, then, it seems unlikely that the act of moving a site-specific work would comprise sufficient originality to constitute the creation of an infringing derivative work, although the relocated work itself should be deemed a "distmguishable variation" and thus an unauthorized derivative work. If, for example, "Tilted Arc" were to be moved intact and displayed on the Atlantic City boardwalk, the relocated work might be deemed an unauthorized derivative work.

In any case, the artist has protection only if she retains the copyright. Thus, if Serra had retained copyright, he might have argued that removal of "Tilted Arc" did not destroy the work, but rather created a derivative work which is a distinguishable variation from the original site-specific work, and therefore infringed his copyright under section 106(2). Unfortunately, this strategy may have little actual usefulness to artists. Serra, a sculptor of international renown, did not retain the copyright. It does not seem likely that commissioned artists will often retain authorship, even after Reid. ${ }^{174}$

\section{d. The Fair-Use Doctrine}

Copyright's protection of moral rights is also significantly limited by section 107, which codifies the "fair use" doctrine. ${ }^{175}$ Section 107 provides that "fair use of a copyrighted work . . . for purposes such as criticism [or] comment . . . is not an infringement of copyright." 176 The section refiects a balance between the exclusive pecuniary rights provided by copyright and the free flow of information. Personality rights of the artist necessarily must also be tempered by the social policies underlying the section. As a result, courts may find that in individual cases an artist may have to accept perceived mutilations or objectionable contextual uses or displays. ${ }^{177}$ If, as some have advocated, the first amendment defense of fair use is expanded, such a development would further extend the incursions upon moral rights permitted by copyright law. ${ }^{178}$

172. Id. at $490-91$.

173. Barnett, supra note 157, at 474 (endorsing the standard of Bell rather than Batlin in cases where the consequence of finding a derivative work is liability for the work's maker).

174. See supra text accompanying notes 114-16.

175. 17 U.S.C. $\S 107$ (1988).

176. Id. The statute is not of direct concern to site-specific artists because, while section 107 allows parodies to be made of a site-specific work, it does not allow any alteration of the original work. Because the site-specific artist's primary interest is the integrity of the work in its environmental context, the fair-use rule is not particularly relevant.

177. See Kwall, supra note 33, at 64-68. The application of the "fair use" defense to fine art seems truly inapposite. See infra note 376 and accompanying text.

178. See generally Note, Copyright, Free Speech, and the Visual Arts, 93 YALE L.J. 1565 (1984) (authored by Patricia A. Krieg), reprinted in 15 J. ARTS MGMT. \& L. 59 (1986). 
Copyright offers limited protection for the moral rights of creators retaining copyright. Artists who no longer hold copyright in their artworks may avail themselves only of conjectural protections under sections 501, 203, and 304. Even for those artists who do retain copyrights, the work-for-hire, first-sale, and fair-use doctrines limit protection of the paternity and integrity interests and may permit destruction, mutilation, and objectionable displays of site-specific and other singular-copy art.

\section{B. Lanham Act Protection of Moral Rights}

Artists have also sought protection of their moral rights under section 43(a) of the Federal Trademark Act, known as the Lanham Act. ${ }^{179}$

179. The Lanham Act was revised in 1989 by the Trademark Law Revision Act of 1988. Pub. L. No. 100-667, 102 Stat. 3935 (codified at 15 U.S.C. $\S \S 1051-1127$ ). The revised section 43(a), effective November 16, 1989, states:

(a) Any person who, on or in connection with any goods or services, or any container for goods, uses in coinmerce any word, term, name, symbol, or device, or any coinbination thereof, or any false designation of origin, false or misleading description of fact, or false or misleading representation of fact, which-

(1) is likely to cause confusion, or to cause mistake, or to deceivc as to the affiliation, connection, or association of such person with another person, or as to the origin, sponsorship, or approval of his or her goods, services, or coinmercial activities by another person, or

(2) in commercial advertising or promotion, misrepresents the nature, characteristics, qualities, or geographic origin of his or her or another person's goods, services, or commercial activities, shail be liable in a civil action by any person who believes that he or she is or is likely to be damaged by such act.

Pub. L. No. 100-667, § 43(a), 102 Stat. 3935, 3946 (1988) (codified at 15 U.S.C. § 1125(a) (1988).

The cases examined in this Comment all consider the previous version of $\S 43(\mathrm{a})$ :

Any person who shall affix, apply, or annex, or use in connection with any goods or services, or any container or containers for goods, a false designation of origin, or any false description or representation, including words or other symbols tending falsely to describe or represent the same, and shall cause such goods or services to enter commerce, and any such person who shall with knowledge of the falsity of such designation of origin or description or representation cause or procure the saine to be transported or used in cominerce or deliver the same to any carrier to be transported or used, shall be liable to a civil action by any person doing business in the locality falsely indicated as that of origin or in the region in which said locality is situated, or by any person who believes that he is or is likely to be damaged by the use of any such false description or representation.

Ch. 79-540, § 43(a), 60 Stat. 427, 441 (1946).

Since both versions of the Lanham Act treat passing off equivalently, examination of $\S 43$ (a) herein should remain relevant. See generally Krigsman, Section 43(a) of the Lanham Act As a Defender of Artists' 'Moral Rights,' 73 TRADEMARK ReP. 251, 262-70 (1983) (discussing cases decided under section 43(a)); Maslow, Droit Moral and Sections 43(a) and 44(i) of the Lanham ActA Judicial Shell Game?, 48 GEO. WASH. L. REv. 377 (1980) (suggesting a judicial trend toward expansive application of Section 43(a)); Sokolow, A New Weapon for Artists' Rights. Section 43(a) of the Lanham Trademark Act, 5 ART \& L. 32 (1980) (discussing the use of section 43(a) as a means of protecting moral rights); Comment, supra note 99, at 480-81 (noting that courts have broadly construed section 43(a) to prevent misuse of artists' names or distortion of their work); Note, supra note 153 (analyzing the Gilliam decision and its implications for the protection of artists' moral rights). But see Annual Review Committee, The Thirtieth Year of Administration of the Lanham Trademark Act of 1946, 67 TRADEMARK REP. 471, 564-68 (1977) (noting that inany artists contract away the protections of section 43(a)); Comment, supra note 153, at 476 (noting the limitations of section 43(a)). 
Section 43(a) has come to function as a law of unfair competition ${ }^{180}$ protecting against consumer confusion, and thereunder artists have obtained protection of paternity and integrity rights. Remedies available to an artist under section 43(a) of the Lanham Act do not require that she own a copyright in her work. In Smith v. Montoro, ${ }^{181}$ a film distributor credited an actor's performance with another actor's name. ${ }^{182}$ The court held that the defendant's alleged act of substitution would constitute "reverse passing off" under section 43(a) and would be actionable. ${ }^{183}$ The court's reasoning implied that an artist has a claim under section 43(a) analogous to the right of paternity if her name is removed from her work. ${ }^{184}$

Yet the Lanham Act's protection of the paternity right is restricted. The holding of Smith v. Montoro may be hmited to cases where an artist's name is replaced with that of another. If an artist's name is simply removed, no misrepresentation occurs unless an audience connects the work to the artist because of its strong secondary meaning. ${ }^{185}$ If there is no such misrepresentation, the artist could only look to the terms of her contract for remedy.

Gilliam v. American Broadcasting Companies ${ }^{186}$ granted protection to artists' integrity rights through its application of the Lanham Act. The court held that the plaintiffs had successfully asserted a claim under section 43(a) in addition to their copyright infringement claim. The court found that $\mathrm{ABC}$ 's edited version of the Monty Python shows "impaired the integrity" of the group's work. ${ }^{187}$ The court also found $A B C$ 's representation of the edited versions as the work of Monty Python to be misleading and thus in violation of section 43(a). ${ }^{188}$ While some have praised the Gilliam decision on this issue, ${ }^{189}$ no court has yet cited the decision for the proposition that section 43(a) protects the right of integrity. ${ }^{190}$

The application of the Act's provisions in Gilliam provided only

180. R. Brown \& R. Denicola, COPYRiGHT 445 (1985).

181. 648 F.2d 602 (9th Cir. 1981).

182. Id. at 603 .

183. Id. at 604-07; cf. Follett v. New Am. Library, Inc., 497 F. Supp. 304, 311 (S.D.N.Y. 1980) (attributions of authorship misrepresenting an author's contribution violate $\S 43(\mathrm{a})$ ).

184. See Note, supra note 76, at 169.

185. Id. at 179 .

186. 538 F.2d 14 (2d Cir. 1976). For a discussion of the application of copyright laws to this case, see supra text accompanying notes 150-53.

187. Id. at 25 .

188. Id. at 25 \& n.13.

189. See Krigsman, supra note 179, at 267 (noting that Gilliam has been hailed as an American case recognizing moral rights); Note, supra note 153, at 624 (discussing the integrity rights protection incident in enforcement of the Lanham Act).

190. See Gantz, Protecting Artists' Moral Rights: A Critique of the California Art Preservation Act as a Model for Statutory Reform, 49 GEo. WASH. L. REv. 873, 879-80 \& n.43 (1981) (noting that Gilliam had not been widely followed up to that time). 
makeshift protection to personality interests. While the court approved "vindicat[ion of] the author's personal right to prevent the presentation of his work to the public in a distorted form,"191 it suggested that the Lanham Act was not intended to be a moral rights law. ${ }^{192}$ Rather, the Act was designed to address problems of false advertising in the sale of goods and services related to trademarks. ${ }^{193}$ In his concurrence, Judge Gurfein similarly criticized the use of section 43(a) to protect the right of integrity because the Lanham Act concerned misdescription of origin. ${ }^{194}$ In his view, if "it is inade clear that the $A B C$ version is not approved by the Monty Python group, there is no misdescription of origin." $195 \mathrm{He}$ found that a disclaimer would have sufficed, whereas the majority beheved otherwise, as did soine commentators. ${ }^{196}$ Even under the majority's rationale, though, it would seem that $A B C$ could have avoided violation of section 43(a) by not attributing the show to Monty Python; althougl the embodiment of the artists' expression of personality would have been violated, there would be no relief under the Lanham Act.

If an artist has contractually declined her right to edit, she cannot invoke a section 43(a) claim. In other words, an artist's moral rights claim under the section is "only as strong as the contract."197 Disregarding this point, the Gilliam court ignored the conspicuous absence of a noediting provision in the BBC-Monty Python contract. Although the court's approach did preserve the plaintiff's copyright and Lanham Act claims, the court's holding would wisely be limited to its unusual facts. Indeed, most artists cannot expect such generous interpretations, nor will they often have the negotiating strength to procure favorable contract terms. Nevertheless, courts have occasionally protected integrity and paternity interests through the application of section $43(\mathrm{a}) .^{198}$

Section 43(a) conjecturally supports a site-specific artist's claim that lier rights to integrity and paternity have been violated if the work is disturbed or relocated yet remains attributed to the artist. The relocation of the steel element of "Tilted Arc" to Philadelphia, still credited to Serra, would have qualified as such a relocation. Although there must be an alteration of the underlying work for a section 43(a) claim to prevail,

191. 538 F.2d at $24-25$.

192. Id. at 24.

193. Comment, supra note 99 , at 481.

194. Gilliam, 538 F.2d at $26-27$ (Gurfein, J., concurring).

195. Id.

196. See, e.g., Annual Review Committee, supra note 179, at 566-67.

197. Note, supra note 76 , at 178 .

198. See, e.g., Jaeger v. American Int'1 Pictures, Inc., 330 F. Supp. 274, 278 (S.D.N.Y. 1971) (noting that plaintiff author/director had a tenable claim under section 43(a) because defendant credited plaintiff as author/director of an allegedly mutilated version of plaintiff's film); Geisel v. Poynter Prods., Inc., 295 F. Supp. 331, 351-55 (S.D.N.Y. 1968) (defendants violated section 43(a) by creating false impression that plaintiff author authorized dolls based on his creations). 
there is no clear standard of actionable alteration. ${ }^{199}$ If a court did not recognize the importance of the environmental context of a site-specific work like Serra's, it might find that relocation of such a work does not constitute an actionable alteration. Further, if the work is so distorted as to be unrecognizable as the work of the artist, there can be no claim of damage to the artist's reputation or claim of imsattribution. ${ }^{200}$ Section 43(a) actions by site-specific artists thus will fail if the work is no longer remimiscent of the artist's original work, and the distorted version is not attributed to the artist. While the Lanham Act lends some protection to the paternity imterest, the imtegrity imterest remains easily damaged.

\section{Common Law Actions}

American courts have rehed upon a variety of actions outside of federal statutory law to confer protection upon the artist analogous to moral rights. ${ }^{201}$ The threshold problem confronting artists using these substitute actions to vindicate their inoral rights is the difficulty of conforning a personality rights claim to an action designed to protect pecuniary interests. ${ }^{202}$ Since the "analogous" state common law actions and the moral rights doctrine have different objectives, any protection of personality interests achieved under the state actions are fortuitous. ${ }^{203}$ Artists are forced to mold their clains to satisfy the elements of alternative remedies, elements often at odds with a moral rights claim. Even if an artist is able to adjust her action, the inconsistent protection accorded by varying courts renders recovery unpredictable. ${ }^{204}$ In addition, some courts may be reluctant even to permit these analogues to safeguard personahity interests, because the artists' suits are based upon the unrecognized notion of moral rights. ${ }^{205}$ In any case, artists will often contract away their existing protections.

Although some courts interpret ambiguous contracts to the advantage of artists, ${ }^{206}$ courts are often reluctant to read into such agreements

199. Note, supra note 76 , at $178-79$.

200. Id. at 179.

201. See Krigsman, supra note 179, at 254-62 (discussing non-statutory remedies for moral rights incursions). Some commentators have suggested that these substitutes offer sufficient protection to the personality rights of artists. See, e.g., Treece, American Law Analogues of the Author's 'Moral Right', 16 AM. J. CoMP. L. 487 (1968-69) (arguing that artists are adequately protected by common law substitutes); Comment, Toward Artistic Integrity: Implementing Moral Right Through Extension of Existing American Legal Doctrines, 60 GEO. L.J. 1539 (1972) (suggesting that common law doctrines, though presently inadequate, could be extended to successfully protect moral rights).

202. Kwall, supra note 33, at 23-24; Note, supra note 76, at 180.

203. Kwall, supra note 33 , at 24.

204. See Note, supra note 76 , at $180-81$.

205. Note, Protecting the Public Interest in Art, 91 YALE L.J. 121, 124 (1981) (authored by Ellen R. Porges).

206. See, e.g., Curwood v. Affiliate Distribs., 283 F. 219, 222-23 (S.D.N.Y. 1922) (sale of film 
rights regarding which the contract is silent. ${ }^{207}$ Courts have often rejected paternity and integrity claims after examining the terms of the contract. If a contract is silent on the question, artists have found relief only froin excessive mutilations. ${ }^{208}$ For example, in Preminger $v$. Columbia Pictures, ${ }^{209}$ although the plaintiff film owner held the rights to final editing of the motion picture, the contract contained no provision regarding editing for television. The court held that prevailing industry standards governed television editing limits and that plaintiff could not obtain relief for editing actually done by Columbia. ${ }^{210}$ Sinnilarly, in Stevens v. National Broadcasting Co. ${ }^{211}$ the contract between a filin producer and a television network did not mention editing rights. The court permitted editing for commercials that did not einasculate the filin's artistic quality. ${ }^{212}$ Both decisions reject the view that film producers have the riglit to have their films shown on television as originally produced. ${ }^{213}$

If, however, an artist contracts away the riglit to inake clianges, and hence her interest in the integrity of the work, courts will enforce the contract even if such clianges would amount to a substantial alteration or mutilation. In Seroff v. Simon \& Schuster, Inc. ${ }^{214}$ plaintiff author sued his publisher for libel based upon the distorted translation of his book. The court found the defendant not liable because the contract granted translation rights to the publisler. ${ }^{215}$

The foregoing primciple similarly affects tlie paternity right. Absent an express contractual provision, an artist cannot compel attribution of her name to her work. Thus in Vargas v. Esquire, Inc., ${ }^{216}$ an artist could not compel a inagazine publislier to attribute autliorship to hin when it publislied his drawings, simply because lie had not extracted an enforceable agreeinent requiring the magazine to do $\mathrm{so.}^{217}$

rights to story did not include author's permission to allow purchaser to attach author's name to any picture produced by purchaser).

207. See Comment, supra note 153, at 473. But see Gilliam v. American Broadcasting Cos., 538 F.2d 14 (2d Cir. 1976). For a discussion of Gilliam, in which the court granted relief to artists on an implicit moral rights claim although their contract was silent on the issue of protection of moral rights interests, see supra notes $150-59$ and accompanying text.

208. Kwall, supra note 33, at 21.

209. 49 Misc. 2d 363, 267 N.Y.S.2d 594, (Sup. Ct.) aff'd per curiam, 25 A.D.2d 830, 269 N.Y.S.2d 913 (App. Div. 1966).

210. Id. at $370-71,267$ N.Y.S.2d at $602-03$.

211. 270 Cal. App. 2d 886; 76 Cal. Rptr. 106 (Dist. Ct. App. 1969).

212. Id. at 893, 76 Cal. Rptr. at 110; see also McGuire v. United Artists Television Prods., Inc., 254 F. Supp. 270 (S.D. Cal. 1966) (absence of contractual provision prevented writer from enjoining assignee from deleting portions of television show in order to insert commercials).

213. Kwall, supra note 33, at 21 n.77.

214. 6 Misc. 2d 383, 162 N.Y.S.2d 770 (Sup. Ct. 1957).

215. Id. at $389-91,162$ N.Y.S.2d at 776-78.

216. 164 F.2d 522 (7th Cir. 1947).

217. Id. at 526; see also Wolfe v. United Artists Corp., 583 F. Supp. 52, 56 (E.D. Pa. 1983) 
The parties to a typical contract for artistic work negotiate from disparate bargaining positions. The commissioner of the work is often a large, for-profit organization such as a magazine, motion picture company, or other private corporation with a great deal of business sophistication. Alternatively, the commissioner may be a federal, state, or local government accustomed to negotiatimg for public works. The artist, on the other hand, is often unsophisticated in contract negotiation and unable to afford competent counsel. Additionally, artists have frequently disregarded the dangers of contractual concessions, preferring to focus their energies on the prospective artwork. Site-specific artists of wellknown works, such as the designer of the Vietnam War Memorial, Maya Ling Lin, have contracted away their rights to the contextual integrity of their works; after all, the artist being granted such a coveted commission is not likely to jeopardize her opportunity by demanding contractual protection of paternity and integrity interests. From this perspective, contract remedies work against artists, who typically have little bargaining power.

Contract law's greatest weakness in protecting moral rights, however, is the requirement of privity: The artist will often not be in a direct contractual relationship with the alleged violator. ${ }^{218}$ Works of art change hands, and successors to the original purchaser cannot be bound by a contract the original purchaser negotiated with the artist. Any alternative system of servitudes on paintings, drawings, and sculpture would likely prove to be unworkable because it would require a new unwieldy system of public records of transactions affecting artwork. ${ }^{219}$

As argued above, alternate remedies often fail because of the difficulty of conforming a moral rights claim to the elements of the substitute theory. ${ }^{220}$ State unfair competition law, for example, works to safeguard economic, not personal, rights, and to avert consumer deception. ${ }^{221}$ Actions based on such statutes therefore require proof of likelihood of confusion, competition, and passing off, ${ }^{222}$ elements not usually satisfied in a pure moral rights claim.

Defamation actions are inadequate for similar reasons. First, pro-

(authorship attribution is determined by the agreement between the parties); Clemens v. Press Publishing Co., 67 Misc. 183, 183-84, 122 N.Y.S. 206, 207 (Sup. Ct. 1910) (contract, construed to reflect the intent of the parties, prevented publisher from omitting author's name from story); $c f$. Granz v. Harris, 198 F.2d 585 (2d Cir. 1952) (discussing whether a musician could prevent a record company from attributing an edited version of his work to him).

218. See Diamond, supra note 33 , at 257.

219. Merryman, supra note 28 , at 1043-44.

220. See supra notes 202-05 and accompanying text.

221. State unfair competition laws generally operate similarly to section 43(a) of the Lanham Act. 15 U.S.C. $\S 1125$ (a) (1988). See supra note 179 for text of the statute. For a discussion of the operation of the Lanham Act, see supra notes 193-94 and accompanying text.

222. See, e.g., American Washboard Co. v. Saginaw Mfg. Co., 103 F. 281, 284 (6th Cir. 1900). 
tection of reputation, while overlapping somewhat with personality interests, ${ }^{223}$ encompasses a narrower range of rights. While moral rights seek to safeguard the personality of the artist and the act of creation, an action for libel aims only to protect that artist's exploitable reputation and the pecuniary incidents of her work. ${ }^{224}$ Courts hearing defamation actions in moral rights cases often apply the technical rules narrowly. ${ }^{225}$ To prevail, an artist must show that the violation of the paternity or integrity right held her up to contempt or ridicule and damaged her reputation. ${ }^{226}$ This is a difficult showing, ${ }^{227}$ especially if the artist is a well-known public figure. ${ }^{228}$ Richard Serra, like most sculptors of commissioned public art, is such an individual. Even if Serra had not been a public figure, ${ }^{229}$ it is unlikely he could have proved that public ridicule damaged his artistic reputation.

Invasion-of-privacy actions are also of limited utility in moral rights cases. The scope of protection varies from state to state, and may or may not terminate at death. Some states have codified the right of privacy in a form resembling right-of-publicity causes of action. ${ }^{230}$ Often, an artist who has sold an artwork using her name or likeness is excepted from right-of-privacy statutes. Such exceptions often prove to be insurmountable in moral rights actions ${ }^{231}$ because they fail to recognize that paternity and integrity interests survive the sale of the artwork. ${ }^{232}$ Moreover, invasion-of-privacy actions, intended to protect an artist's proprietary interest in her reputation, fail to safeguard the work of important or wellknown artists. ${ }^{233}$ Famous artists often create site-specific and other public artworks, which perhaps have the greatest value as cultural prop-

223. See supra notes $99 \& 132$ and accompanying text.

224. See. Note, supra note 153 , at 617 .

225. See, e.g., Harris v. Twentieth Century-Fox Film Corp., 43 F. Supp. 119 (S.D.N.Y. 1942) (libel action dismissed for failure to plead special damages).

226. See W. Keeton, D. Dobbs, R. Keeton \& D. Owen, Prosser and Keeton on the LAW OF TORTS $\S 111$, at 773 (5th ed. 1984).

227. See, e.g., Geisel v. Poynter Prods., Inc., 295 F. Supp. 331, 357 (S.D.N.Y. 1968) (no defamation when defendants exercised care in manufacturing dolls based on plaintiff's characters so as to cause no injury to plaintiff's professional reputation).

228. See Note, supra note 205 , at $124 \&$ n. 19.

229. See Gertz v. Robert Welch Inc., 418 U.S. 323, 351-52 (1974) (plaintiff in a defamation action was not a public figure because there was no evidence of his general fame or notoriety in the community); Waldbaum v. Fairchild Publications, Inc., 627 F.2d 1287, 1294 (1980) (plaintiff, as limited public figure, was precluded from recovery for libel in absence of actual malice).

230. See Kwall, supra note 33, at $26 \mathrm{n} .91$ (citing New York, Oklahoma, and Virginia statutes).

231. See, e.g., Geisel, 295 F. Supp. at 356-57 (defendant's manufacture of dolls based on cartoon featuring plaintiff's characters not a violation of privacy statute, when plaintiff had sold copyrights to defendant).

232. Note, supra note 153, at 619.

233. Comment, supra note 201 , at $1548-49$ \& n.59. See generally Warren \& Brandeis, The Right to Privacy, 4 HARv. L. Rev. 193 (1890). 
erty. ${ }^{234}$ As a result, the celebrity of an artist like Serra precludes any privacy action on his part, just as it diminishes his prospects in a defamation action.

Actions under a right-of-publicity theory are as ineffective as privacy actions in protecting moral rights. While the privacy action has traditionally served as a means of compensating individuals for their injured feelings, the publicity action focuses not upon the existence of that injury but rather upon the loss of pecuniary gain involved in an unauthorized exploitation. ${ }^{235}$ For a site-specific artist to recover on a right-of-publicity theory, she would have to show that an unauthorized individual has appropriated a likeness of her work for commercial purposes. ${ }^{236}$ Because a site-specific artist seeks to maintain the integrity of her work by preventing its unauthorized alteration rather than preventing its commercial exploitation, the right-of-publicity theory is inapposite. Thus, the theoretical objectives of the publicity right differ from moral rights' goal of protecting personahity interests; consequently, the artist will again be confronted with the problem of molding her claim to the elements of a substitute cause of action. Beyond the issue of its differing theoretical basis, the right of publicity is an evolving doctrine of presently undetermined scope, ${ }^{237}$ which further undermines its usefulness in protecting moral rights.

\section{State Moral Rights Statutes}

Ten states have recently enacted statutes protecting the rights of paternity and integrity in certain artworks. ${ }^{238}$ In some commentators' view, the adoption of these statutes strengthens the conclusion that the composite of American laws protects moral rights. ${ }^{239}$ Most attention has focused on the California and New York approaches, which respectively emphasize integrity and paternity. ${ }^{240}$ The other states enacting moral

234. Note, supra note 205 , at 125 n.21.

235. Kwall, Is Independence Day Dawning for the Right of Publicity?, 17 U.C. DAvis L. REv. 191, 191 (1984).

236. Id. at 202-03.

237. Id. at 191 .

238. See Cal. Civ. Code $\S 987$ (West Supp. 1989); ConN. Gen. Stat. AnN $\S 42-116$ t (West Supp. 1989); LA. Rev. STAT. ANN. § 51:2151-:2156 (West 1987); ME. Rev. Stat. ANN. tit. 27, $\S 303$ (Supp. 1987-1988); MASS. GEN. LAws ANN. ch. 231, § 85s (West Supp. 1988); N.J. STAT. ANN. \$ 2A:24A-1 to -8 (West 1987); N.M. STAT. ANN. § 13-4B-3 (1987); N.Y. ARTS \& CuLT. AFF. LAw $\S 14.01-.03$ (McKinney 1984) [hereinafter N.Y. LAw]; PA. STAT. ANN. tit. 73, $\S ~ 2101-2110$ (Purdon Supp. 1987); R.I. GEN. LAws $\$$ 5-62-2 to -6 (1987).

239. BERNE REPORT, supra note 68 , at 34 n.67.

240. See, c.g., Damich, supra note 44, at 1741; Davis, State Moral Rights Law and the Federal Copyright System, 4 CARDozo ARTS \& ENT. J. 233 (1985); Engdahl, Moral Rights in State Statutes: A Comparison of the California Art Preservation Act and the New York Artists' Authorship Rights Act, 34 COPYRIGHT L. SyMp. (ASCAP) 203 (1987); Francione, The California Art Preservation Act and Federal Preemption by the 1976 Copyright Act-Equivalence and Actual Conflict, 31 COPYRIGHT L. 
rights legislation have modeled their statutes upon one or the other of these two. Consequently, either preservation or attribution is primarily emphasized, but neither approach grants full moral rights protection. In addition, the enactment of such state laws raises serious questions about possible conflicts with the laws of other states and with federal copyright protection.

\section{The California Approach}

In the California Art Preservation Act, ${ }^{241}$ the California Legislature recognized artists' moral rights in concluding that fine art "is an expression of the artist's personality"242 and that "the physical alteration or destruction of fine art . . . is detrimental to the artist's reputation."243 The California Act enforces the artist's right of integrity by protecting artwork from intentional physical defacement, mutilation, alteration, or destruction. ${ }^{244}$ Further, the Act grants the artist the right to claim, or disclaim for valid reasons, authorship of a work, thus protecting the right of paternity. ${ }^{245}$

The Act limits its coverage to works of "fine art," defined as "an original painting, sculpture, or drawing, or an original work of art in glass . . but [not including] work prepared under contract for commercial use by its purchaser." ${ }^{246}$ Artists may waive their rights, but must do so expressly in writing. ${ }^{247}$ The duration of protection is coextensive with copyright-the life of the artist and fifty years thereafter; ${ }^{248}$ thus, heirs may bring a moral rights action on the artist's behalf. The artist or her representative must bring the suit within one year of discovery of the violation or within three years of the complained of action, whichever is longer. ${ }^{249}$ In addition, suits may be brought on behalf of artists by cer-

SYMP. (ASCAP) 105 (1982); Gantz, Protecting Artists' Moral Rights: A Critique of the California Art Preservation Act as a Model for Statutory Reform, 49 GEO. WASH. L. REV. 873 (1981); Karlen, Moral Rights in California, 19 SAN DIEGo L. REv. 675 (1982); Petrovich, Artists' Statutory Droit Moral in California: A Critical Appraisal, 15 LoY. L.A.L. REv. 29 (1981); Scott \& Cohen, An Introduction to the New York Artists' Authorship Rights Act, 8 ART \& L. 369 (1984); Note, The New York Artists' Authorship Rights Act: Increased Protection and Enhanced Status for Visual Artists, 70 CORNEL. L. REV. 158 (1984) (authored by Sarah Ann Smith) [hereinafter Note, Enhanced Status]; Note, California Art Preservation Act: A Safe Hamlet for 'Moral Rights' in the United States, 14 U.C. Davis L. Rev. 975 (1981) (authored by Deborah Ann Chan).

241. Cal Civ. Code $\S 987$ (West Supp. 1989).

242. Id. § 987(a).

243. Id.

244. Id. $\S 987(\mathrm{c})(1)$. If the work is damaged during framing, conservation, or restoration, the statute has been violated if the act was grossly negligent. Id. $\$ 987(\mathrm{c})(2)$.

245. Id. \& 987(d).

246. Id. § 987(b)(2).

247. Id. \$ 987(g)(3).

248. Id. $\S 987(\mathrm{~g})(1)$.

249. Id. § 987(i). 
tain recognized others in the interest of preserving the work. ${ }^{250}$

The California Art Preservation Act further limits its protection to works of "recognized quality." To determine whether a work meets this standard, a trier of fact is to rely on the opinions of "persons involved with the creation or marketing of fine art."251 Such a threshold standard of quality runs the risk of involving the judiciary in aesthetic judgments, an endeavor discouraged by Justice Holmes in Bleistein v. Donaldson Lithographing Co. ${ }^{252}$ The Act's quality assessment process might also leave unprotected unusual or avant-garde works, works by new artists, or even works by popular artists scorned by the art establishment. ${ }^{253}$ Quality determinations also raise the specter of censorship; if a work offends those judging it, the judges may decide that the work fails the "recognized quality" test. ${ }^{254}$

If "Tilted Arc" had been erected in California, Serra might have had a cause of action under the Preservation Act. Removal from its environmental context should violate the Act as an intentional alteration of the work. Yet the protection of "Tilted Arc" would depend on a finding that it was of "recognized quality." Given the controversy generated by the work and the strong reaction of people against it, it cannot be assumed that a trier of fact, relying on the opinions of art experts, would have found the requisite "recognized quality." Without such a finding, the Preservation Act affords absolutely no protection to the work.

The Preservation Act does permit artists to waive their rights, although waiver must be expressly in writing. ${ }^{255}$ Moreover, an artist is deemed to have waived all rights under the Act in any of her works of fine art that "cannot be removed from a building without substantial physical defacement, mutilation, alteration, or destruction."256 Most murals, then, including Alfred Crimi's famed fresco of a barechested Christ, ${ }^{257}$ would not be protected under the Act.

250. Id. $\$ 989$.

251. Id. $\$ 987(\mathrm{f})$.

252. 188 U.S. 239, 251 (1903) ("Cilt would be a dangerous undertaking for persons trained only to the law to constitute themselves final judges of the worth of pictorial illustrations").

253. Davis, supra note 240 , at 238-39.

254. Note, supra note 76 , at $185-86$. The danger of censorship implicit in quality assessment also arises in obscenity cases. See Miller v. California, 413 U.S. 15, 24 (1973) (art otherwise deemed obscene exempted if of "serious literary, artistic, political or scientific value"). Would the unsettling "body art" of Chris Burden be "serious art" of "recognized quality"?

255. Cal. CIv. Code $\S 987(g)(3)$ (West Supp. 1989).

256. Id. § 987(h)(1).

257. See Crimi v. Rutgers Presbyterian Church, 194 Misc. 570, 89 N.Y.S.2d 813 (Sup. Ct. 1949) (dealing with a church's decision to paint over a fresco it deemed offensive). 


\section{The New York Approach}

The New York Artists' Authorship Rights Act ${ }^{258}$ shifts the emphasis of protection from the integrity of the artwork to the attribution of authorship. Given the focus of the Authorship Act upon the artist's reputation, its sponsors evidently intended it to guarantee only the right of paternity. ${ }^{259}$ The New York statute provides limited protection to a broader array of works than does the California Act. The statute again protects only "fine art," 260 but requires no showing of "recognized quality."261 And it prohibits alteration or mutilation only when "damage to the artist's reputation is reasonably likely to result."262

Because the statute focuses on attribution and the paternity interest rather than preservation and the integrity interest, it provides no protection to a work unless it is "knowingly displayed in a place accessible to the public, published or reproduced in [New York]."263 Hence, mutilations of works closeted in private collections are not actionable. Moreover, if a mutilated or altered work is not attributed to the artist, she has no cause of action unless "it would reasonably be regarded as being the work of the artist, and damage to the artist's reputation is reasonably likely to result therefrom." 264 It is difficult to prove damage to reputation, ${ }^{265}$ particularly if an artist is not yet established. Thus, the statute accords only very limited protection to the paternity interest and negligible protection to the integrity interest, and neither are realistically available to an artist who enjoys no reputation. Moreover, it would seem that the statute cannot prevent total destruction of an artwork, for nothing would remain to reflect adversely on the creator's reputation. ${ }^{266}$

New York limits this minimal protection in two critical ways. No one other than the artist may bring an action under the New York statute, and the artist's rights are not extended posthumously to her heirs (unlike both the California Art Preservation Act and the Copyright Act). ${ }^{267}$ Thus New York leaves a substantial part of the artist's paternity interest unprotected and slights her integrity interest.

258. N.Y. LAW, supra note 238.

259. Note, Enhanced Status, supra note 240, at 170-71.

260. N.Y. LAW, supra note $238, \S 14.03(3)(\mathrm{e})$.

261. Note, supra note 76 , at 189.

262. N.Y. LAw, supra note $238, \S 14.03(1)$.

263. Id. $\S 14.03(3)(\mathrm{e})$.

264. Id. $\S 14.03(1)$.

265. See Davis, supra note 240 , at 242 (arguing that this standard imposes an undue burden on artists).

266. See Damich, supra note 44, at 1741. Damich notes, however, that destruction of the only copy of an artist's work may damage her reputation. Id. at 1741-42.

267. See N.Y. LAw, supra note 238, $\S 14.03$ (4) (an artist may obtain relief for a violation of the Act but must bring the action within three years of the action complained of or one year after the constructive discovery of the deed). 
The federal court hearing Serra's case, finding it had no jurisdiction over Serra's contract, copyright, and trademark claims, declined jurisdiction over his state law claims as well. ${ }^{268}$ Still, had Serra been able to argue his case under the New York Artist's Authorship Act, he might have obtained recovery to the extent he could prove injury to his reputation. Although relocating "Tilted Arc" would certainly constitute an alteration of the work, if the GSA no longer attributed it to Serra, he might not have a cause of action. Nor would Serra have a claim if the Court deemed the sculpture destroyed unless he could show that the publicity surrounding the destruction of "Tilted Arc" had injured his reputation. Thus, Serra could not prevent the removal of "Tilted Arc" under the New York Act, and hence could not prevent its conceptual destruction. He could only prevent the attribution of his name to the altered work.

\section{Problems of Conflict and Preemption of State Statutes}

Other shortcomings of the state statutes' defense of personality rights arise out of the American federal system itself. The protection of a state statute extends only as far as the state's jurisdiction. Therefore, owners of "fine art" objects living in California or in Massachusetts can alter those works outside of those states without being subject to the protections of their statutes. ${ }^{269}$

This problem gives rise to anomalies that highlight the need for uniformity among state statutes, and that can be successfully addressed only by a uniform state statute or a federal law. For example, since California emphasizes preservation and New York stresses reputation, an artwork could be altered in New York and thereafter publicly displayed in California without giving rise to liability in either state. ${ }^{270}$ The California and Massachusetts statutes are also ambiguous regarding the accrual of a cause of action. ${ }^{271}$

The possibility that federal copyright law preempts the state laws presents the most serious problem with relying upon state statutes for moral rights protection. Section 301 of the 1976 Copyright Act ${ }^{272}$ describes a two-pronged test for determining whether the provisions of the 1976 Act preempt a State law. First, the Act will not preempt state laws that do not concern "works of authorship that are fixed in a tangible medium of expression and come within the subject matter of copy-

268. Serra v. United States Gen. Servs. Admin., 667 F. Supp. 1042, 1046-52 (S.D.N.Y. 1987).

269. Note, supra note 76 , at 198-99.

270. Koegel, Memorandum of Support for S.2796: Introduced in the 99th Congress by Senator Edward M. Kennedy (D. Massachusetts), 11 Colum.-VLA J. L. \& ARTS 347, 352 (1987).

271. See Note, supra note 76, at 199.

272. 17 U.S.C. $\S 301$ (1988). 
right." ${ }^{273}$ States are thus free to protect intangible, unfixed expression, such as visual performances, without being preempted. Second, the section 301 test permits the states to safeguard rights that are "not equivalent to any of the exclusive rights within the general scope of copyright." 274

This second prong can be difficult to apply. The state law must not be "equivalent" to any of the exclusive rights enumerated in section 106: reproduction, adaptation, distribution, public performance, and display. ${ }^{275}$ The literature suggests at least two ways to determine equivalency. One approach takes the form of an "extra elements" test, as described by Professor Nimmer. ${ }^{276}$ If the exercise of any of the exclusive rights under section 106 infrimges the state law, then that law is preempted; if, however, other elements are required to constitute an infringement, the law is not preempted. ${ }^{277}$ The second approach criticizes the "extra elements" test because it ignores conflicts between the purposes and effects of state and federal regulation-a fundamental principle underlying preemption. ${ }^{278}$ This "objectives" approach argues that a state law is preempted if its purpose and effect conflict with federal copyright provisions. ${ }^{279}$

The Califorma Preservation Act arguably survives preemption under the "extra eleınents" approach because a plaintiff inust prove elements in addition to those required under federal copyright law. ${ }^{280} \mathrm{Spe}-$ cifically, the work at issue inust have been "fine art" of "recognized quality,"281 a showimg not required under the Copyright Act. The narrow himits of the New York and other state statutes similarly seem to protect them from preemption under the "extra elements" test. ${ }^{282}$ But the "objectives" test leads some cominentators to conclude that the state moral rights statutes are preempted because all the statutes seek to pro-

273. Id. §301(a), (b)(1).

274. Id. §301(b)(3).

275. Id. § 106 .

276. See 1 M. NimmER \& D. NimmER, supra note 120, § 101[B], at 1-14 to 1-15.

277. Id; see, e.g., Allied Artists Pictures Corp. v. Rhodes, 496 F. Supp. 408, 443 (S.D. Ohio 1980), aff'd in part and remanded in part on other grounds, 679 F.2d 656 (6th Cir. 1982); see also Damich, supra note 44, at 1737-38; Davis, supra note 240, at 247; Francione, supra note 240, at 122 24; Gantz, supra note 240, at 896. But see Harper \& Row, Publishers v. Nation Enters., 501 F. Supp. 848, 851 (S.D.N.Y. 1980), rev'd on other grounds, 723 F.2d 195, 200 (2d Cir. 1983), rev'd on other grounds, 471 U.S. 539 (1985) (holding that laws must protect qualitatively different rights to avoid preemption).

278. See Davis, supra note 240 , at 249-50.

279. See id. at 250; Francione, supra note 240 , at 138 . But see Kwall, supra note 33 , at $78-79$ (criticizing "objectives" approach as too speculative).

280. See Damich, supra note 44, at 1738; Francione, supra note 240, at 130-38; Gantz, supra note 240, at 897-98; Note, supra note 76, at 194.

281. CAL. Civ. Code $\S 987$ (b)(2), (c)(1) (West Supp. 1989).

282. Note, supra note 76, at 195. 
tect the artists' work. ${ }^{283}$ Others, however, argue that the state moral rights statutes protect personality, not mercenary interests, and thus pursue a different objective than federal copyright law. ${ }^{284}$

A third approach to determining preemption is simply to compare the rights shielded by the state statutes with those protected by copyright. If those interests conflict, the state statute should be considered preempted. ${ }^{285}$ Under this approach, state protections for paternity appear to conflict with provisions of sections 109(c) and 106(5) of the Copyright Act. Section 109(c) allows the owner of a copy to publicly display that copy without attributing authorship to its creator, regardless of whether he also owns the copyright. ${ }^{286}$ Under section 106(5), a copyright owner's exclusive right of display similarly entitles him to display the work without crediting the artist. ${ }^{287}$ Thus, state statutes that protect the paternity interest by requiring authorship attribution arguably conflict with federal copyright protection and should be preempted. ${ }^{288}$

Similarly, it can be argued that state laws that protect the integrity right will conflict with provisions of the Copyright Act. A creator retaining the copyright in his work can prevent attributed mutilated adaptations under section $106(2){ }^{289}$ Even without copyright ownership, an artist may be able to qualify as a "beneficial owner" under section 501 and sue for infringement. ${ }^{290}$ Hence, state laws protecting an artist from mutilated derivative works attributed to her risk preemption because they seek to defend interests equivalent to those protected by copyright. $^{291}$ The same reasoning applies to unattributed mutilations; state laws protecting against uncredited altered versions conflict with the protections of sections 106(2) and 501. Further, since section 109(a) permits owners of copies to destroy them, ${ }^{292}$ any state law preventing destruction or mutilation amounting to destruction would be preempted. Moreover, state laws protecting an artist's integrity right against objectionable contextual displays could conflict with a copy owner's right to display his

283. See, e.g., Kwall, supra note 33, at 78 \& n.317; Note, supra note 76 , at 195 (discussing the arguments against finding preemptions under the objectives test).

284. See Damich, supra note 44 , at 1737-38; Davis, supra note 240 , at 257; Francione, supra note 240 , at $125-30$.

285. Kwall, supra note 33 , at 80,86 .

286. See 17 U.S.C. $\S 109$ (b) (1988); see also Kwall, supra note 33 , at 88 (arguing that state protection of paternity may conflict with section 109(b)).

287. 17 U.S.C. $\S 106(5)$ (1988).

288. Kwall, supra note 33 , at 88-89.

289. See supra notes $161-73$ and accompanying text.

290. 17 U.S.C. $\$ 501($ b) (1988). For a discussion of the beneficial-owner doctrine, see supra notes 129-32 and accompanying text.

291. Kwall, supra note 33 , at 89.

292. 17 U.S.C. $\$ 109$ (a) (1988) (the owner of a copy of a work has the right to "sell or otherwise dispose of" the copy). For a discussion of the application of the "otherwise dispose of "language of section 109(a), see supra notes $143-49$ and accompanying text. 
copy under section $109(\mathrm{c})^{293}$ and the copyright owner's right of display under section 106(5).

From the foregoing, it is manifest that section 301 of the 1976 Copyright Act threatens to preempt state protection of the paternity and integrity interests. At the very least, the possibility of preemption may discourage states from providing broader moral rights protections. ${ }^{294}$ Further, those state statutes that do exist provide only limited protection. Moral rights protection is inextricably bound up with the protections afforded by copyright. Because Congress has constitutional power over copyright, Congress, not the states, should provide protection to personality rights. The need for national uniformity in place of ad hoc determinations by state legislatures militates in favor of broad federal protection of moral rights.

\section{E. First Amendment Protection of Artistic Expression}

When Richard Serra sued the General Services Administration to enjom the agency fron removing "Tilted Arc," the court dismissed his contract, copyright, tradeniark, and state law claims and granted summary judgment on Serra's first ainendment claini. ${ }^{295}$ Serra appealed the latter judgment to the Second Circuit, ${ }^{296}$ alleging that removal of the site-specific work would violate his right to free speech. Such claims had succeeded, though rarely, in the past. In Sefick v. City of Chicago, ${ }^{297}$ an artist had successfully argued that the city's efforts to remove his public sculpture would infringe his free speech rights.

Although in Serra's case the Second Circuit acknowledged that artwork may constitute speech for purposes of the first amendment, the court nonetheless held that the artistic expression in "Tilted Arc" belonged to the Governmient. ${ }^{298}$ The United States Government was the "speaker" because it owned both the sculpture and the plaza. The court stated that Serra relinquished his speech rights in the sculpture when he sold it. If Serra had wished to retain control over the work's display, the court noted, he could have bargained to reserve those rights. ${ }^{299}$ Because Serra had not done so, the Government was the speaker, and as such could regulate its own speech. ${ }^{300}$ "In this country," said Serra subsequently, "the right of property exceeds all other rights. Art is property,

293. See supra notes $124-25$ and accompanying text.

294. See Note, supra note 76, at 196.

295. Serra v. United States Gen. Servs. Admin., 667 F. Supp. 1042 (S.D.N.Y. 1987).

296. Serra v. United States Gen. Servs. Admin., 847 F.2d 1045 (2d Cir. 1988).

297. 485 F. Supp. 644 (N.D. I11. 1979) (removal of satirical sculpture from public building held to be a first amendment violation).

298. Serra, 847 F.2d at $1048-49$.

299. Id. at 1049.

300. Id. at 1048 . 
and if you sell your art, you've sold your free speech."301

The Second Circuit's holding in Serra essentially disposed of the possibility that an artist could substitute first amendment claims for moral rights actions when she no longer owned the copy at issue. Obviously, it is only remotely likely that artists will retain ownership of any public art, particularly government-commissioned, site-specific art. Hence, governmental bodies will nearly always enjoy the discretion to display or remove from display artwork they own. "They say that the content of that speech is theirs," commented Serra. "They say their property rights grant them power over my moral rights." 302

Although the Serra court concluded that the Government controlled the artwork, it did consider the possibility that the artist retained some first amendment interest im the contmued display of "Tilted Arc." The court held that even if Serra had such an interest, the Government's removal of the "Arc" would be a permissible time, place, and manner restriction. Such restrictions are vahid if they comport with the requirements developed by the Supreme Court in Clark v. Community for Creative Non-Violence ${ }^{303}$ and United States v. O'Brien. ${ }^{304}$ Under these two decisions, restrictions are valid if they are content neutral, are narrowly tailored to further a significant governmental interest, and leave alternate chaimels of communication available. ${ }^{305}$ The court found that the Government's interest im an unobstructed Federal Plaza could only be furthered by the "Arc"'s removal. ${ }^{306}$ Further, alternative channels remaimed available for Serra's speech, and the GSA's decision to remove the work was not content based. ${ }^{307}$

Such reasoning should be troubling to all public artists. The Serra case allows the government to dispose of public art without violating the first amendment. Such a rule practically allows the government to remove pieces it finds distasteful. Yet at the same time the Constitution constrains government from using content-based criteria when commissioning artwork, even if its permissible assessments of artistic quality are often ultimately mfluenced by illegitimate considerations of the artwork's viewpoint. ${ }^{308}$

Indeed, the GSA's motive in removing "Tilted Arc" appears somewhat questionable. Although the interest of achieving an unobstructed

301. Solomon, supra note 9 , at 74.

302. N.Y. Times, Mar. 11, 1989, § 1, at 30, col. 5 .

303. 468 U.S. 288 (1984).

304. 391 U.S. 367 (1968).

305. Clark, 468 U.S. at 293.

306. Serra, 847 F.2d at 1049 .

307. Id. at 1050.

308. See Sobel, First Amendment Standards for Government Subsidies of Artistic and Cultural Expression: A Reply to Justices Scalia and Rehnquist, 41 VAND. L. REV. 517, 524-27 (1988). 
plaza is not clearly content based, there is ample reason to suspect that the GSA's true objection to "Tilted Arc" was an improper aesthetic one, as Serra alleged. ${ }^{309}$ If, given the record before it, the Serra court could hold that the "significant governmental interest" at stake was content neutral, then it seems likely that courts will permit governmental bodies to consider aesthetic criteria implicitly, if not explicitly.

In fact, the court defended the legitimacy of aesthetic regulation by the government, perhaps sensing the fragility of its content-neutrality finding. The court cited Board of Education v. Pico ${ }^{310}$ for the proposition that a governmental body can exercise content-based discretion, but not "in a narrowly partisan or political manner." ${ }^{11}$ Moreover, the court pointed out, the Supreme Court has approved the use of aesthetic considerations by the government. ${ }^{312}$ The court also cited Piarowski v. Illinois Community College ${ }^{313}$ and Close v. Lederle, ${ }^{314}$ two circuit court decisions criticized by commentators, ${ }^{315}$ for the notion that the state may regulate the display of art based upon aesthetic qualities. ${ }^{316}$

The Serra court's view does reflect the state of first amendment theory. Many commentators believe that artistic expression deserves protection only to the extent that it resembles or influences political expression. ${ }^{317}$ The Supreme Court has never adequately considered artistic expression in its own right. ${ }^{318}$ Artistic expression, especially nonrepresentational art like "Tilted Arc," often contains noncognitive and emotional aspects, while first amendment analysis has traditionally protected only the expression of cognitive political ideas. ${ }^{319}$ Although Justice Harlan in Cohen v. California ${ }^{320}$ suggested that the Constitution ought to protect emotive as well as cognitive communication, ${ }^{321}$ the Court has instead carved out categories of less protected speech characterized by their emotive content. ${ }^{322}$ The jurisprudence clearly reflects

309. Serra, 847 F.2d at 1050.

310. 457 U.S. 853 (1982) (considering the removal of objectionable books from school libraries).

311. Id. at $870-71$.

312. Serra, 847 F.2d at 1051 (citing City Council v. Taxpayers for Vincent, 466 U.S. 789, 805-07 (1984) (upholding a Los Angeles municipal code prohibiting the posting of signs on public property); Metromedia, Inc. v. City of San Diego, 453 U.S. 490, 507-08 (1981) (upholding a San Diego ordinance prohibiting billboards)).

313. 759 F.2d 625, 630-32 (7th Cir. 1985), cert. denied, 474 U.S. 1007 (1985).

314. 424 F.2d 988, 990 (1st Cir. 1970), cert. denied, 400 U.S. 903 (1970).

315. See 1 J. Merryman \& A. ElsEN, supra note 1, at 292-93; Nahmod, Artistic Expression and Aesthetic Theory: The Beautiful, the Sublime, and the First Amendment, 1987 W1S. L. REV. 221, 247-48 (1987).

316. Serra, 847 F.2d at 1051.

317. Nahmod, supra note 315 , at $222,235-42$.

318. Id. at 243-44.

319. Id. at 244.

320. 403 U.S. 15 (1971).

321. Id. at 25-26.

322. Nahmod, supra note 315, at 247. 
hostility towards nonpohtical speech.

This hostility toward nonpolitical speech is even nore distinct in the lower courts. In Close v. Lederle, ${ }^{323}$ the First Circuit permitted a university to remove an art instructor's exhibition of unsettling paintings, finding the artist's first amendment interest "minimal" and the paimtimgs lacking in political expression. ${ }^{324}$ Similarly, in Piarowski v. Illinois Community College, ${ }^{325}$ the Seventh Circuit accorded an artist's paintings less than absolute first amendment protection, im part because they were not political expressions, but simply "art for art's sake."326

Artistic expression should be accorded full first amendment protection. There can be no valid distinction between aesthetics and the first amendment "if the [first amendment's] solicitude for commumication and self-fulfillinent interests is to have any meaning at all." ${ }^{327}$ Consequently, the government's claim that it is promoting beauty through aesthetic regulation should not be permitted to "override the [artist's] coinpeting first ainendment claim" to promote her own view of beauty. ${ }^{328}$ John Costoms has argued that beyond the seeming impropriety of setting a standard of beauty, aesthetic regulation calmot even intelligibly define beauty within a first amendment framework well enough to avoid being struck down as void for vagueness. 329

Similarly, a visual-beauty approach to the aesthetic regulation of art considered offensive is neither "narrowly drawn" nor advances a "substantial governinental interest" that outweighs the artist's interest in artistic expression. ${ }^{330}$ According to Costoms, a content-based approach to aesthetic regulation will be legitimate only if it balances the artist's fully recognized first amendment interests with those of the community in preventing the cultural instability and psychological dissonance that can result from the entry of a new landmark into the coinmunity. Such a balancing must be performed in accordance with current first amendment standards regarding speech. ${ }^{331}$

One other troubling aspect of the Serra decision should be noted. The court asserted that Serra would have alternative channels for speech after "Tilted Arc" had been inoved. Serra had already "spoken" via the

323. 424 F.2d 988 (1st Cir.), cert. denied, 400 U.S. 903 (1970) (holding based on "captive audience" doctrine).

324. Id. at 990 .

325. 759 F.2d 625 (7th Cir.), cert. denied, 474 U.S. 1007 (1985) (holding based on "captive audience" doctrine).

326. Id. at 628.

327. Costonis, Law and Aesthetics: A Critique and a Reformulation of the Dilemmas, $80 \mathrm{Mich}$.

L. REv. 355, 448 (1982).

328. Nahmod, supra note 315 , at 258.

329. See Costonis, supra note 327 , at $410-11$.

330. Id. at 412 (quoting Schad v. Borough of Mt. Ephraim, 452 U.S. 61,68 (1981)).

331. Id. at 453-57. 
"Arc" for six years, the court noted, and the first amendment does not guarantee "the freedom to continue speaking forever."332 Notwithstanding the site-specific nature of "Tilted Arc," the Serra court said the artist could express his views through other means. ${ }^{333}$

While it may or may not be true that the first amendment does not guarantee the right of a speaker to contmue speaking indefinitely, the court's reasoning was nevertheless flawed. The court evidently believed that destroying an artist's past work does not suppress her speech if she is still capable of creating new works-a view that betrays a thorough misunderstanding of the nature of artistic expression. Visual art inextricably binds coguitive and emotive ideas and is thus often incapable of explication. Put simply, the content of visual art cannot be separated from the vehicle of communication. ${ }^{334}$ The key to an artwork's value is the inseparability of form and content;"335 in Marshall McLuhan's phrase, "the medium is the message." 336 As a result, "[d]estroying the message's physical embodiment destroys the message itself."337 Thus, Serra's speech is inextricably embodied in "Tilted Arc" and could never separately be expressed in alternative channels. The speech of "Tilted Arc" was forever silenced when the sculpture was dismantled and removed from Federal Plaza.

Given the subordmate status of artistic expression, artists' first amendment claims will often prove inadequate to vindicate the artists' personality interests im paternity and integrity. If government ownership of artwork transforms it into government speech, an artist's claim of censorship when that work is removed from display will fail.

\section{III}

\section{Federal Legislative Recognition of THE MORAL} RIGHTS OF SITE-SPECIFIC AND OTHER VISUAL

\section{ARTISTS}

The "minimalist" approach to Berne inaintains that "by stitching together . . . cases, the visual art statutes, Monty Python, and other scraps and fragments, we can fashion a loincloth, or at least a G-string, that will cover our moral rights nakedness." 338 "Minimalism" results in a cumbersome American system. As Professor Roeder noted nearly a half-cen-

332. Serra v. United States Gen. Servs. Admin., 847 F.2d 1045, 1050 (2d Cir. 1988).

333. Id.

334. Nahmod, supra note 315 , at $245-46$.

335. See H. Rosenberg, The New as Value, in The Anxious Object: ArT Today and Its AUDIENCE 232-33 (1964) (arguing that innovations that expand consciousness often take new forms because form and content are inseparable).

336. See M. McLuhan, Understanding Media 7 (2d ed. 1964).

337. Costonis, supra note 327 , at 450 .

338. Brown, supra note 74, at 204. 
tury ago, "The apphication of so many different doctrines to a subject matter which is imtrinsically homogeneous produces confusion; choice of theory becomes dependent on a fortuitous combimation of factors, rather than on the basic needs of the problem."339 Once one reviews the inadequacies of substitute protections, the truth emerges clearly: Our law does not respond when the artist claims a violation of a personality imterest rather than a property interest. ${ }^{340}$

The "minimalist" view's reluctance to exphicitly protect moral rights betrays its unwarranted fear of acknowledging that rights other than ownership subsist in artwork. The Berne debate illustrates the continuing tension in federal intellectual property policy between artists' rights and owners' rights, a tension that affects the public availability of artistic works. ${ }^{341}$ Yet American jurisprndence's attempts at fashioning makeshift analogues to safeguard paternity and integrity reflect an implicit acknowledgeinent of personality interests. For inoral rights are not alien to American culture; rather, they developed in western nations with whoin we have a shared cultural base. ${ }^{342}$ The United States should take the next step and exphcitly acknowledge, as article 6 bis of Berne does, ${ }^{343}$ that there is an unseverable psychological nexus between the artist and the work she imbues with her personality and that nexus requires the protection of the law.

Perhaps the inost powerful argument against substitute theories and for federal inoral rights legislation arises frow the inferior bargaining power of all but the most celebrated artists. As previously discussed, ${ }^{344}$ inost coinmissioners or patrons of art are large and powerful governinental or business entities that can usually require artists to contract away any protections they 1might have had under analogous clains. Given these realities, the law should tip the bargaining balance toward artists by recognizing their moral rights. If a purchaser wishes to take a work free of the legal rights of integrity and paternity, he should bargain for it and contractually acquire the artist's consent. ${ }^{345}$ A commissioner would then

339. Roeder, supra note 33 , at 575.

340. Merryman, supra note 28 , at 1039.

341. See Note, supra note 67 , at 489 (noting that the struggle between work-for-hire proponents and moral rights advocates reflects the tension in copyright policy between artists' rights and the public availability of art).

342. See Merryman, supra note 28, at 1043 (discussing the application of moral rights to America).

343. See Note, supra note 67 , at 490 .

344. See supra notes 217-18 and accompanying text.

345. This argument has been made by several commentators. See Brown, supra note 74, at 208 (advocating tipping balance initially toward creator in the artist-buyer relationship); DaSilva, supra note 29, at 56-57 (explaining that civil law countries have ensured artists' rights in unequal bargaining situations through the moral rights doctrine); Merryman, supra note 28, at 1044 (arguing that the establishment of a legal right of imtegrity in the artwork will equalize power in the artistbuyer relationship). 
have to reckon with the artist's recognized moral rights in order to exploit a work, a factor that gives the artist a slightly more powerful position from which to negotiate.

In addition to protecting the artist's personality interests, federal moral rights legislation serves the public interest. Protection of integrity preserves artwork in its original, undistorted form for otlers to see. Artists can safeguard the true version for posterity. Moreover, art represents a facet of our national culture and history. Granting artists private enforcement of their personality riglits will vindicate society's interest in preservation of artistic culture. ${ }^{346}$ Certainly, protecting artists' integrity rights along witl their economic rights ${ }^{347}$ will serve the constitutional provision that grants Congress the power "[t]o promote the Progress of ... [tlie] useful Arts." ${ }^{\text {348 }}$ A federally recognized moral right for visual artists would protect the personality interests that are inadequately safeguarded by disingenuous and inelegant makeshift substitutes. Moreover, federal recognition would accord with the theoretical basis of Berne-an acknowledgement of the continuing nexus between artist and work after sale. $^{349}$ Finally, uniform legislation would recoguize that the art market is national and would remove conflicts among varying state laws. ${ }^{350}$

In defending its "minimalist" stance on Berne adherence, the House Judiciary Committee allowed that furtler protection of artists' rights had been and would continue to be considered by both Houses of Congress. It noted that the Senate Judiciary Committee held hearings in both the 99th and 100th Congresses to consider legislation, introduced by Senator Edward Kennedy of Massachusetts, to protect the paternity and integrity rights of visual artists. ${ }^{351}$ Kennedy reintroduced a revised version of the Visual Artists Rights Act in the first session of the 101st Congress, ${ }^{352}$ and Representatives Kastenmeier and Markey introduced a companion bill in

346. See Merryman, supra note 28, at 1041 .

347. See Transcript of statement by Peter H. Karlen, Visual Rights Act of 1989: Hearings on S. 1198, Before the Subcomm. on Patents, Copyrights, and Trademarks of the Senate Comm. on the Judiciary, 101st Cong., 1st Sess. 5 (June 20, 1989) [hereinafter Karlen, Statement] (unpublished transcript on file with author); see also Transcript of statement by Prof. Edward J. Damich, Visual Rights Act of 1989: Hearings on S. 1198 Before the Subcomm. on Patents, Copyrights, and Trademarks of the Senate Comm. on the Judiciary, 101st Cong., 1st Sess. 1 (June 20, 1989) [hereinafter Damich, Statement] (noting that federal legislation protecting moral rights would not introduce a foreign concept into American law) (unpublished transcript on file with author).

348. U.S. CoNST. art. I, $\S 8$, cl. 8.

349. See Note, supra note 67 , at $491-92$ (charging lawmakers with having gone to "creative lengths" in the past to avoid Berne's moral rights mandate).

350. See Karlen, Statement, supra note 347, at 9; see also supra note 270 and aecompanying text (discussing the inconsistent protection afforded moral rights in California and New York).

351. BERNE REPORT, supra note 68, at 40 \& n.91; see, e.g., Visual Artists Rights Amendment of 1986: Hearings on S. 2796 Before the Subcomm. on Patents, Copyrights and Trademarks of the Senate Comm. on the Judiciary, 99th Cong., 2d Sess. (1986).

352. S. 1198, 101st Cong., 1st Sess., 135 Cong. Rec. S6811 (daily ed. June 16, 1989) [hereinafter S. 1198]. 
the House of Representatives. ${ }^{353}$ The Senate and House versions offer similar protections for artists.

The Kennedy bill would amend section 106 of the Copyright Act by adding subsections that grant limited rights of paternity and integrity to creators of pictorial, graphic, or sculptural works. ${ }^{354}$ Each bill protects both rights regardless of whether the artist retamed copyright, and both rights survive for the life of the artist plus fifty years (provided the artwork was created on or after the legislation's effective date). ${ }^{355}$ The Kennedy bill is narrowly drafted and extends protection only to singular works or limited editions. ${ }^{356}$

Both the House and Senate bills adequately protect the paternity right. The bills give an artist the right to claim authorship of her work, to prevent the attribution of her name to any work she did not create, and to prevent the use of her name as author of a work which has been destroyed, mutilated, or otherwise modified. ${ }^{357}$ Yet even broader protections should be enacted. The bills do not enable the artist to demand either anonymity or pseudonymity, as WIPO envisions the Berne Convention to require. ${ }^{358}$ Additionally, if a work is not altered but is displayed in an objectionable context, the artist has no remedy for a violation of her paternity interest unless she can show that the consequent harm rose to the level of distortion.

The House and Senate bills differ significantly in their protection of the integrity interest. In the Senate bill, an artist may "prevent any distortion, mutilation, or other modification of $\operatorname{th}[\mathrm{e}]$ work which would be prejudicial to her honor or reputation." 359 Although there is no requirement of any finding of quality before an artist can claim the protections of this provision, the artist must show damage to her honor or reputation. In order to prevent the destruction of the artwork, however, she must show that the work is of "recognized stature" as set out in the bill. ${ }^{360}$

In the House version, if a work is not of "recognized stature," its artist can prevent its mutilation or destruction only if she can show that it would injure her honor or reputation. If, on the other hand, the work is shown to be of "recognized stature," its mutilation or destruction

353. H.R. 2690, 101st Cong., 1st Sess., 135 CoNG. Rec. E2199 (daily ed. June 20, 1989) [hereinafter H.R. 2690].

354. S. 1198, supra note 352 . It has been suggested that the bill's coverage be broadened to include other works of fine art such as collages and mosaics. See Karlen, supra note 347, at 14.

355. S. 1198, supra note $352, \S 3($ a); H.R. 2690, supra note 353, § 3(a).

356. S. 1198, supra note $352, \S 2(a)$.

357. See id. § 3(a); H.R. 2690, supra note 353, §3(a).

358. Damich, Statement, supra note 347 , at 8.

359. S. 1198, supra note 352 , §3(a).

360. Id. 
constitutes a per se prejudice to the artist's honor or reputation. ${ }^{361}$ The distinction made in the Kennedy bill between mutilation and destruction is never an easy one, for works normally deemed destroyed can often be restored if enough money and effort is expended. ${ }^{362}$ In any case, although both bills utilize a questionable quality standard, the House version offers a somewhat broader protection of the integrity interest.

In the Kennedy bill, "persons involved with the creation, appreciation, history or marketing" of artwork ${ }^{363}$ make the finding of "recognized stature" necessary to prevent the destruction of such work. ${ }^{364}$ It is unclear why the Senate bill imposes the quality criterion on the right against destruction but not on the right against mutilation. As Professor Edward Damich pointed out at the Senate hearings: "If the 'prejudicial to honor or reputation' qualification is sufficient to make law suits unattractive in the case of the right against modification, it would seem to be equally serviceable in the case of destruction."365 A stature requirement raises the same concerns of aesthetic censorship that the "recognized quality" requirement in the California Art Preservation Act generates. ${ }^{366}$ Moreover, no "quality" test has previously been incorporated into federal copyright doctrine, ${ }^{367}$ and the stature requirement adds little to the law. For instance, if the prospective defendant commissioned the work, he is usually estopped from denying the "stature" or "quality" of the work because he commissioned it the way it was. ${ }^{368}$ The primary effect of the requirement is to discourage unknown artists from protecting their interests. Fears that removing the stature requirement would result in an avalanche of trivial suits appear unfounded. The economics of suing should discourage trivial claims. Moreover, European countries with moral rights regimes have not experienced the feared fiood. Furthermore, cases in the United States that have considered moral rights have not been frivolous ones. ${ }^{369}$

Although the bills' preemption provisions would provide national uniformity, they run the risk of nullifying state laws that provide greater protection than would the federal statute. The bills preempt state laws that provide rights "equivalent" to those conferred by the bills. "Equivalence" is a difficult concept: As this Comment has shown, the

361. H.R. 2690, supra note 353, § 3(a).

362. See Karlen, Statement, supra note 347, at 18-19.

363. S. 1198 , supra note $352, \S 3$ (a).

364. Id.

365. Damich, Statement, supra note 347, at 8.

366. See supra notes 251-54 and accompanying text.

367. Note, supra note 76, at 203.

368. See Karlen, Statement, supra note 347, at 17-18.

369. Damich, State "Moral Rights" Statutes: An Analysis and Critique, 13 Colum.-VLA J.L. \& ARTS 291, 300-01 (1989).

370. S. 1198 , supra note 352 , § 5; H.R. 2690 , supra note 353 , $\S 5$. 
term has proven problematic in section 301 of the Copyright Act of 1976. ${ }^{371}$ Language that could avoid this hazard would preempt only those state laws that would "diminish or prevent the exercise of the rights conferred by, or the implementation of" the federal statute. ${ }^{372}$

Also troubling to site-specific artists is the bills' exclusion of works made for hire from the definition of protected visual artworks. ${ }^{373}$ The work-for-hire provision in copyright law gives copyrights to the commissioner of the work. Moral rights, as protected by the proposed statute, exist independently of copyright. Thus, there appears to be no rationale for the noted exclusion simce moral rights in the bills apply to the owners of both the copyright and the artwork. Granting the commissioner of a work for hire the right to violate the artist's integrity rights gives the commissioner special rights not held by other copyright owners. As Professor Damich pointed out, it is "difficult to see why there should be a need for a special freedom to make physical changes to a [commissioned] painting, drawing, primt, or sculpture that does not exist in the case of owners of copyright and the material object."374 This exclusion should be omitted from any enacted legislation.

Both bills make section 107 of the Copyright Act, the "fair use" provision, fully apphicable to the inoral rights provisions. ${ }^{375}$ It is unclear how the destruction or inutilation of an artwork or the withholding of attribution could ever be deemed a fair use. Therefore, a fair-use defense should be limited to the repair of an artwork when the artist refuses to make such repairs. ${ }^{376}$

Both bills also incorporate a provision found in the California statute. ${ }^{377}$ If a work cannot be removed from a building without "destruction, distortion, inutilation, or other modification of the work," the protections of the bills do not apply, except as otherwise agreed in writing. ${ }^{378}$ As a result, inost murals, including Crimi's fresco, ${ }^{379}$ would receive no more protection from the bills than current law provides. Although the resultimg loss of artworks is unfortunate, the provision reflects the European position, which balances the rights of artists and owners.

The foregomg limitations are certainly the result of political coin-

371. Damich, Statement, supra note 347, at 5-6. For a discussion of the preemption problem, see supra notes $272-93$ and accompanying text.

372. Damich, Statement, supra note 347 , at 6 .

373. See S. 1198, supra note 352, § 2; H.R. 2690 , supra note $353, \S 2$.

374. Damich, Statement, supra note 347 , at 7.

375. See S. 1198, supra note 352, § 8; H.R. 2690, supra note 353, $\S 8$.

376. Karlen, Statement, supra note 347 , at 15-16.

377. See CAL. Crv. CODE $\$ 987($ h)(1) (West 1982 \& Supp. 1989); see also supra notes 256-57 and accompanying text.

378. S. 1198 , supra note 352 , § 4; H.R. 2690, supra note $353, \S 4$.

379. See supra note 257 and accompanying text. 
promise, but the bills are a step in the right direction. Protection of moral rights should logically begin with those works that would be lost by irreparable physical alterations. ${ }^{380}$ Although one commentator has criticized the Kennedy bill because it limits its application to pictorial, graphic, and sculptural works, ${ }^{381}$ Kennedy's approach is justified. All "arts" should not be lumped together; there are separately recognizable spheres of visual arts, performing arts, and literary arts. Visual arts ought to be treated independently in inoral rights legislation because most visual artwork is singular. Questions of "adaptation" and "interpretation" of original visual artwork are really questions about alteration or mutilation of the master version, and thus are distinguishable from comparable issues in the performing and literary arts. ${ }^{382}$ The Kennedy bill properly notes this distinction and accordingly focuses on singular works or limited editions. ${ }^{383}$ Nevertheless, the foregoing criticisins in this Comment should be addressed in any enacted federal legislation.

Federal moral rights legislation in the United States will necessarily take an American approach. Our law has steadfastly avoided recognizing artists as a special class. Rather, American law has tended to protect artists' rights on a pragınatic basis, which reflects a constitutionally recognized social purpose, ${ }^{384}$ and has sought to balance equitably the interests of artists with those who coinmercially exploit artwork. ${ }^{385}$ In a society that has historically characterized artworks as objects of commerce, a balancing approach that weighs the personality interests of the artist against competing economic and public interests is the inost appropriate. $^{386}$ Moral rights can become a part of American law only if they are adapted into this multilateral policy tradition, which recognizes that society has an interest in facititating the diffusion of art and in stimulat-

380. See Transcript of statement by Prof. Robert A. Gorman, Visual Rights Act of 1989: Hearings on S. 1198 Before Subcomm. on Patents, Copyrights, and Trademarks of the Senate Comm. on the Judiciary, 101st Cong., 1st Sess. 8 (June 20, 1989) [hereinafter Gorman, Statement] (noting that the problems inherent in protecting moral rights in the film and publishing industry are not present in the protection of a singular work) (unpublished transcript on file with author).

381. See Note, supra note 76 , at 207-08.

382. See Merryman, supra note 28, at 1045-46.

383. S. 1198, supra note 352, §2. As noted in the hearings regarding S. 1198 :

[A]rt works are the product of individual inspiration and not collaboratively produced under entrepreneurial supervision, their principal economic value typically rests in their singular manifestation and only rarely in their exploitation in derivative forms and subsidiary markets, and there is typically lacking any kind of elaborate network of contractual relationships that surround the production and marketing of the work. The kind of conduct that the bill would forbid rarely has any redeeming social value or artistic purpose.

Gorman, Statement, supra note 380 , at 8 .

384. U.S. CONST. art. $1, \S 8$, cl. 8.

385. See DaSilva, supra note 29 , at 54-55.

386. See Kwall, supra note 33, at 92. 
ing new art forms and new inethods of exploitation. ${ }^{387}$

Therefore, in order properly to develop inoral rights in American art, commerce, and jurisprudence, any federal legislation inust confront the issue of waiver and alienability of moral rights. Conceptually, it is by definition impossible to alienate a right of personality. France accordingly considers the right inalienable. ${ }^{388}$ Yet "inalienability" is too capacious a term; ${ }^{389}$ transferability and waiver of moral rights must each be considered independently. This becoines clear when one notes that France will enforce contracts that allow alterations that, while more than de minimus, do not distort tlie spirit of the work. ${ }^{390}$ French theory and apphication can be reconciled by a separate examination of transfer and waiver. Because it is conceptually abhorrent to forfeit "ownership" of a personality right, assignment or transfer of paternity and integrity interests are forbidden; however, an artist may waive her right to enforce those rights as against a specified purchaser or commissioner. The Berne Convention and member countries, including West Gerniany, permit contractual inodification of inoral riglits. ${ }^{391}$ The artist is legally endowed with the rights, and buyers who wish to take free of them must acquire the artist's express consent. The artist thus has not "ahenated" an "inalienable" right but has inerely waived her ability to enforce that right against a specified party in the future.

The permissibility of waiver should be incorporated into a federal moral rights bill. While tle House bill permits written waiver of moral rights, ${ }^{392}$ the Senate bill exphicitly forbids waiver. ${ }^{393}$ The possibility of waiver best accords with the American tradition of balancing the interests of the artist with those of the purchaser and the public. An inalienable inoral right could benefit only a few celebrated and powerful artists, thus reducing public access to artwork and limiting the opportunities of developing artists. Conversely, a freely waivable moral right inight not alter the bargaining balance between artist and purchaser or commissioner $^{394}$ and could lead to boilerplate waivers in commission contracts. ${ }^{395}$ One commentator has also argued that the sale by artists of their personality rights undercuts the public benefit of cultural preservation. $^{396}$

387. See DaSilva, supra note 29 , at 57-58.

388. See supra note 57 and accompanying text.

389. See Brown, supra note 74, at 207 \& n.62.

390. See supra notes 57-59 and accompanying text.

391. See Merryman, supra note 28, at 1044.

392. H.R. 2690, supra note $353, \S 3(\mathrm{e})$.

393. S. 1198 , supra note $352, \S 3(\mathrm{e})$.

394. See Kwall, supra note 33 , at 95 (arguing that if a moral right is freely alienable, producers and publishers will always secure releases from artists).

395. See Damich, Statement, supra note 347 , at 9.

396. See Note, supra note 76, at 208 \& n.340. 
Perhaps, then, only reasonable waivers should be permitted, waivers that do not violate the "spirit" of the work. ${ }^{397}$ Additionally, any provision permitting written waiver also must protect artists from being coerced into granting waivers. ${ }^{398}$

In any case, the most practical and most American solution is to tip the bargaining balance toward artists by granting them waivable moral rights. Such a shift is possible while still recognizing a property owner's interest in his property and protecting society's interest in preserving its culture. If a purchaser or commissioner wishes to take free of the risk of the artist enforcing her rights, he must bargain for and contractually acquire the artist's waiver. ${ }^{399}$ If the artist does not wish to grant unreasonable or even reasonable infringements of absolute paternity or integrity, she may refuse to do so.

The granting of a waiver may not be held to bind the artist with regard to subsequent purchasers. The second owner of the artwork and the artist cannot be bound by privity, for the contract of sale in which the artist waived her personality rights was only between the artist and the first purchaser. Requiring the second owner to acquire a waiver if he seeks to make reasonable alterations or to display the artwork without attribution should not be seen as forcing the second buyer to take "subject" to any conditions. Because the personality rights will subsist in all works of art by statute, all purchasers will be deemed to know that all artworks are protected by moral rights unless modified by contract. This analysis underscores the argninent of many that the recognition of moral rights changes a property owner's rights by forbidding him to modify artworks he possesses. It can be acknowledged, then, that moral rights do alter the legal defimition of property without conceding that this definition conflicts with the fundainental notions of property ownership, since the recognition of moral rights defeats no legitimate expectations of the purchaser. ${ }^{400}$

Duration and enforcement of moral rights should follow the general Berne approach, which makes moral rights at least coextensive with copyright. A perpetual right, as recognized by the French, is antithetical to the American balancing approach, and would prove too difficult to administer. The posthumous continuance of moral rights protects the artist's reputation, which lives on, from injury. Further, society's interest in preserving the integrity of its cultural heritage mandates the safeguardimg of artists' original contributions. Moral rights should therefore

397. See Kwall, supra note 33, at 95.

398. See Karlen, Statement, supra note 347, at 13.

399. See supra note 345 and accompanying text.

400. See Merryman, supra note 28 , at 1047-48. 
vest in the family of the deceased artist or in a governmental body. ${ }^{401}$ It inay be possible to extend the enforcement of moral rights beyond the life-plus-fifty period by vesting the right for qualified works with an enforcement agency. While such an approach would require the utilization of the oft-criticized quality standard, works that do not qualify for extended protection would at least have enjoyed protection for life-plusfifty. It is true that any posthumous or agency enforcement of inoral rights would be a statutory exception to the theoretical prohibition on assignment, but the public interest in preserving its cultural heritage justifies this exception.

Legal recognition of a waivable inoral right will lead to different bargaining terms and final commission contracts for site-specific artists. Provisions for prospective removal of the work or alteration of the site will necessarily become exphicit points in negotiation. A federally protected inoral right may provide satisfactory protection for the site-specific artist with regard to objectionable contextual displays. Any federal bill inust inake exphicit, as Kennedy's does not, that the artist's reasonable objections to contextual uses or displays will be considered a violation of her paternity interest and the integrity interest. For site-specific art, site alteration would constitute such an objectionable display. Statutory protection from such display or alteration will allow the site-specific artist to protect against the disruption of a work's contextual integrity. Thus, Maya Ling Lin could have contractually provided that the Vietnam Veterans Meinorial is a site-specific work and specified the exact parameters of the site. She could thereby have prevented the addition to the site of Frederick Hart's statuary and flagpole. It is possible that even if she did not contractually specify the site, under the protections of a carefully drafted federal statute she could reasonably claim that addition of the statuary would be an objectionable site alteration and violation of her integrity interest.

Naturally, site-specific artists like Serra maintain that particular works cannot be removed or relocated without being destroyed. If the artist does not wish the work to be removed from its intended site, she should insist on this provision in the contract. But "permanent" installations have often proved ephemeral, ${ }^{402}$ except perhaps for the Sphinx. A commissioning body will probably not agree, especially after the "Tilted Arc" affair, to install a site-specific artwork pernianently. Thus, even a federal moral rights bill inay not be able to prevent the reinoval of an unpopular public artwork. But if moral rights had been available to Serra before the "Arc" was commissioned, he would at least have been able to negotiate favorable terms with regard to any future removal. Per-

401. See supra notes 61-63 and accompanying text.

402. See 1 J. MERRYMAN AND A. ELSEN, supra note 1, at 407. 
haps he could have specified conditions under which the work could be removed, or required an empirical assessment of public disapproval, or even provided for compensation in the event of a conceptual destruction. Site-specific artists, and all artists of commissioned works, should also contractually require that they be permitted to buy back the commissioned work if it must be removed or relocated to a site of which they disapprove. ${ }^{403}$ It may be too much to expect that artists will be able to negotiate such a provision, $m$ which case it might be included as part of the federal statute; the Califorma Art Preservation Act in fact contains such a provision. ${ }^{404}$

The foregoing analysis may not offer much solace to Richard Serra, but it is in keeping with the traditional American approach of equitably balancing the interests of the artist, the purchaser, and the public.

\section{CONCLUSION}

The dismantling of "Tilted Arc," after a brief stay of execution, highlights the lack of substantive protection for the moral rights of American site-specific artists even after the United States' adherence to the Berne Convention. Reliance upon substitute theories is inadequate and dismgenuous. The Umited States should be ready to recognize formally that there is a special relationship between artists and their work, that artworks are imbued with the personality of the artists, and that artists' stake in protecting these personality interests survives the sale of the work. If American adherence to Berne is to be meaningful, then it must be true to the spirit of article $6 b i s$ and protect the psychological nexus between creator and creation.

A federal moral rights bill must protect reasonable claims of injury to the patermity and integrity interest of all artwork, without application of a quahity standard. The bill must recognize that objectionable contextual display and site alteration constitute violations of the artist's inoral rights. But the legislation must be tempered by an attention to the interests of the public and the coinmissioning bodies as well. Thus, any moral right must be waivable by the artist and enforceable by the artist's heirs or a governmental agency.

Moral rights can become a part of American law only if they are Americanized. A federal moral rights statute that preserves the ability of parties to reach their own terms with regard to the purchase of artwork is in the American tradition. But the scales of negotiation need to be tilted back in the direction of artists by endowing them with moral rights with which to bargain.

403. Id.

404. CaL. Crv. Code $\S 987(\mathrm{~h})(2)$ (West 1982 \& Supp. 1989). 